\title{
Regulating Islamic Financial Institutions: The Nature of the Regulated
}

\author{
By \\ Dahlia El - Hawary \\ George Washington University \\ Wafik Grais \\ World Bank \\ Zamir Iqbal \\ World Bank
}

\begin{abstract}
More than 200 Islamic financial institutions (IFI) are operating in 48 countries. Their combined assets exceed $\$ 200$ billion with an annual growth rate between $12 \%$ and $15 \%$. The regulatory regime governing Islamic financial institutions varies significantly across countries. A number of international organizations have been established with the mandate to set standards that would strengthen and eventually harmonize prudential regulations as they apply to IFI. The paper contributes to the discussion on the nature of the prudential standards to be developed. It clarifies the risks IFI are exposed to and the type of regulation that would be needed to systemically manage them. It considers that the industry is still in a development process whose eventual outcome is the convergence of the practice of Islamic financial intermediation with its conceptual foundations. Accordingly, the paper contrasts the risks and regulation that would be needed in the case of Islamic financial intermediation operating according to a) core principles, and b) current practice. Implications for approaches to capital adequacy, licensing requirements and reliance on market discipline are outlined. An organization of the industry that would allow it to develop in compliance with its principles and prudent risk management, and facilitate its regulation is proposed.
\end{abstract}

\section{World Bank Policy Research Working Paper 3227, March 2004}

The Policy Research Working Paper Series disseminates the findings of work in progress to encourage the exchange of ideas about development issues. An objective of the series is to get the findings out quickly, even if the presentations are less than fully polished. The papers carry the names of the authors and should be cited accordingly. The findings, interpretations, and conclusions expressed in this paper are entirely those of the authors. They do not necessarily represent the view of the World Bank, its Executive Directors, or the countries they represent. Policy Research Working Papers are available online at http://econ.worldbank.org. 


\section{Regulating Islamic Financial Institutions: The Nature of the Regulated ${ }^{1}$}

Over the past few decades, the Islamic financial industry has rapidly expanded worldwide. While it is difficult to identify precisely the date of the first formal Islamic financial institution in recent history, references are often made to the Mitghamr Egypt Savings Association in $1963 .^{2}$ Currently about 240 Islamic financial institutions may have total combined assets in excess of $\$ 200$ billion in more than 48 countries. ${ }^{3}$ Their rapid growth has gained considerable attention in international financial circles where various market participants have recognized promising potentials. According to some estimates, it is expected that Islamic banking will be able to attract $40 \%$ to $50 \%$ of the total savings of the Muslim population worldwide within the next few years. ${ }^{4}$ To capitalize on the potential of that market, a number of global financial institutionsincluding but not limited to, Citibank, Goldman Sachs, BNP-Paris-Bas, and UBS-have established Islamic banking Shariah compatible services in several countries. ${ }^{5}$

The growth opportunity as well as the challenges facing the development of the Islamic financial industry in the global market have raised public policy issues in the jurisdictions in which they operate and internationally. These have led international organizations, international standard setters, national regulatory authorities, policy makers and academia to examine various aspects of Islamic financial intermediation each from their own perspective. Focus has been directed notably on Islamic financial institutions' (IFI's) risk management practices, the broad institutional environment in which they operate, and the regulatory framework that governs them. A number of institutions have been established to become focal points on major issues, in particular the Accounting \& Auditing Organization for Islamic Financial Institutions (AAOIFI), the

\footnotetext{
${ }^{1}$ The authors would like to thank H. van Greuning, J.Hanson and R.van der Bijl as well as participants of a seminar held at the World Bank on October $27^{\text {th }}, 2003$ for their comments.

${ }^{2}$ Ali (2002); see also Archer \& Ahmed (2003).

${ }^{3}$ With some estimates close to $\$ 250$ billion. According to the Association of Islamic Banks, as of 1997 , $29 \%$ of Islamic banks were in South Asia, 20\% in Africa, 18\% in South East Asia and 15\% in the Middle East, $12 \%$ in the GCC countries, 5\% in Europe and America and 1\% in Asia. See Archer \& Ahmed (2003).

${ }^{4}$ Zaher \& Hassan (2001).

${ }^{5}$ Sundarajan and Errico (2002).
} 
International Islamic Rating Agency (IIRA), the Islamic Financial Services Board (IFSB) and the Liquidity Management Center (LMC). ${ }^{6}$

While the rapid expansion of Islamic financing activity has created expectations, it has also raised apprehensions on the risks that may be associated with it. Financial innovation often brings with it changes in the perception of risk. Merton (1995) makes the point that "less apparent understanding of the new environment can create a sense of greater risk even if the objective level of risk in the system is unchanged or reduced". Islamic finance is not immune to such perceptions. The emergence of Islamic finance on the world financial landscape presents challenges similar to that of financial innovation. In line with Merton's observation, it is generating concerns on the inherent risks it presents and their possible spillover on the rest of the financial system as it is less well understood than conventional finance.

This perception is compounded by a number of factors specific to Islamic finance that may add hurdles to its understanding and uncertainty as to the nature of Islamic financial intermediation. First, there is the divergence between the paradigm of Islamic finance, or its theoretic conception, and the way it is practiced in many instances. ${ }^{7}$ $\underline{\text { Second, }}$ actual Islamic financial institutions have to adapt to their environment where they have to compete with conventional financial intermediaries and do not have access to the same money market instruments for liquidity management purposes. Third, each institution's Shariah board and prevailing local legal tradition and interpretations combine with the market's competitive pressure to shape the activity of each Islamic financial institution (IFI). Fourth, in most of the jurisdictions, IFI are still required to comply with the regulations governing conventional financing and to use accounting standards that may not be fully adapted to the substance of their business activities. Fifth, there are variations within the paradigm reflecting five schools of thought, each providing

\footnotetext{
${ }^{6}$ For a description of the role of each institution, see Ali (2002).

7 See for instance Moody's (2001), which reports that "A survey of published accounts indicates that most Islamic banks do not see their on-balance sheet deposits as being profit-and-loss sharing", Special Comment, January.
} 
its own interpretation on the nature of financial transactions and products that may or not be compatible with Shariah. ${ }^{8}$

This paper's objective is a contribution to the clarification of the risks IFI are exposed to and the type of regulation required to systemically manage them. In pursuing this objective, the paper considers that the industry is still in a development process whose eventual outcome is the convergence of practice with conceptual foundations. It consequently distinguishes, for analytical purposes, theoretical and practiced Islamic financial intermediation, the risks they present and the regulation they call for.

In addressing the foregoing issues, the paper deals first in section I with the nature of Islamic financial intermediation, that is the functions it aims to fulfill. Section II then identifies the risks associated with those functions. These two first sections lay the ground for section III, where the nature of regulation that may be needed is considered. In each of the foregoing areas, a distinction is made between the paradigm Islamic financial intermediation and a stylization of prevailing practice. Section IV outlines a vision for the industry. Finally section $\mathrm{V}$ concludes on the challenges lying ahead in the development of a regulatory framework for IFI.

\section{Section I: Functions of Financial Intermediation}

Financial systems are crucial for efficient allocation of resources in a modern economy. Their landscape is determined by the nature of financial intermediation, i.e. how the function of intermediation is performed and who intermediates between suppliers and users of the funds. The acquiring and processing of information about economic entities, the packaging and repackaging of financial claims, and the financial contracting are common elements in the activities that differentiate financial intermediation from other economic activities. ${ }^{9}$

\footnotetext{
${ }^{8}$ The five schools are: Hanafi, Shafei, Hanbali, Maliki and Ibadi. These differences are not further discussed in this paper. Please refer to Saleh (1986).

${ }^{9}$ Draper and Hoag (1978).
} 
The main functions of a financial intermediary are asset transformation, conduct of orderly payments, brokerage and risk transformation. Asset transformation takes place in the form of matching the demand and supply of financial assets and liabilities (e.g., deposits, equity, credit, loans and insurance) and entails the transformation of maturity, scale, and place of financial assets and liabilities of ultimate borrowers and lenders. The function of administration of an accounting and payments system (e.g., check transfer, electronic funds transfer, settlement, clearing) is considered another important intermediation. Typically, financial intermediaries have also offered pure brokerage or match-making between the borrowers and lenders, and facilitated the demand and supply of non-tangible and contingent assets and liabilities, such as collateral, guarantees, financial advice, and custodial services. ${ }^{10}$

Financial intermediaries not only channel resources from capital surplus agents (generally households) to capital deficit ones (corporate sector), they also allow intertemporal smoothing of households' consumption and businesses' expenditures and thus allow both firms and households to share risks. ${ }^{11}$ Since the early 1980s increased financial market complexity and volatility have led financial intermediaries to innovate and offer products to mitigate, transfer and share financial risks. ${ }^{12}$

\section{A - Islamic Financial Intermediation: Nature of Contracts}

One may view the Islamic financial system as grounded in four basic principles: a) risk - sharing -- the terms of financial transactions need to reflect a symmetrical risk/ return distribution each participant to the transaction may face; b) materiality -- a financial transaction needs to have a "material finality", that is it is directly or indirectly linked to a real economic transaction; c) no exploitation - a financial transaction should not lead to the exploitation of any party to the transaction; and d) no financing of sinful

\footnotetext{
${ }^{10}$ Scholtens (1993).

${ }^{11}$ Allen \& Gale (2000).

${ }^{12}$ Demand for risk management and hedging tools suddenly increased after the breakdown of Bretton Woods system in early 1970s, which resulted in increased volatility in foreign exchange and interest rates. Other factors stimulating financial innovations are liberalization of capital accounts, deregulations and breakthroughs in technology. See also Grais \& Kantur (2003) for the impact of these processes on the MENA financial system.
} 
activities such as the production of alcoholic beverages. Financial intermediation based on the principles of Islam has an established historical record and has made significant contributions to economic development over time. Financiers in early periods of Islam were known as sarrafs who undertook many of the traditional and basic functions of a conventional financial institution, such as intermediation between borrowers and lenders, operation of a secure and reliable domestic as well as cross-border payment system, and offering services such as issuance of promissory notes and letters of credit. ${ }^{13}$ Sarrafs operated through an organized network and well-functioning markets, which established them as a sophisticated intermediary given the tools and technology of their time. ${ }^{14}$ There is evidence that some of the concepts, contracts, practices and institutions developed in the Islamic legal sources of the late eighth century provided the foundations for similar instruments in Europe several centuries later. ${ }^{15}$

In Islam, the whole fabric of Divine Law is contractual in its conceptualization, content, and application. Islam forcefully places all economic relations on the firm footing of "contractus". 16 Islamic economics is based on a set of contracts and instruments which form the backbone and building blocks for more complex and elaborate frameworks. ${ }^{17}$

\footnotetext{
${ }^{13}$ For further details see Udovitch (1981), who equated the function of sarrafs with a bank and considered them as "bankers without banks".

${ }^{14}$ Chapra and Ahmed (2002). It is claimed that financial intermediaries in the early Islamic period also helped each other overcome liquidity shortages on the basis of a mutual help arrangement.

${ }^{15}$ Udovitch (1981).

${ }^{16}$ Mirakhor (1989). Contractual foundation of the Shariah judges the virtue of justice in man not only for his material performance but also by the essential attribute of his forthright intention (niyya) with which he enters into every contract. This intention consists of sincerity, truthfulness and insistence on rigorous and loyal fulfillment of what he/she has consented to do (or not to do). This faithfulness to one's contractual obligations is so central to Islamic belief that when the Prophet was asked "who is the believer?" $\mathrm{He}$ replied that "a believer is a person in whom the people can trust their person and possessions."

${ }^{17}$ Several instruments find their roots in the pre-Islamic period but were further developed and widely practiced after confirming their compatibility with the principles of Shariah, i.e. elimination of riba and gharar.
} 


\section{Figure 1}

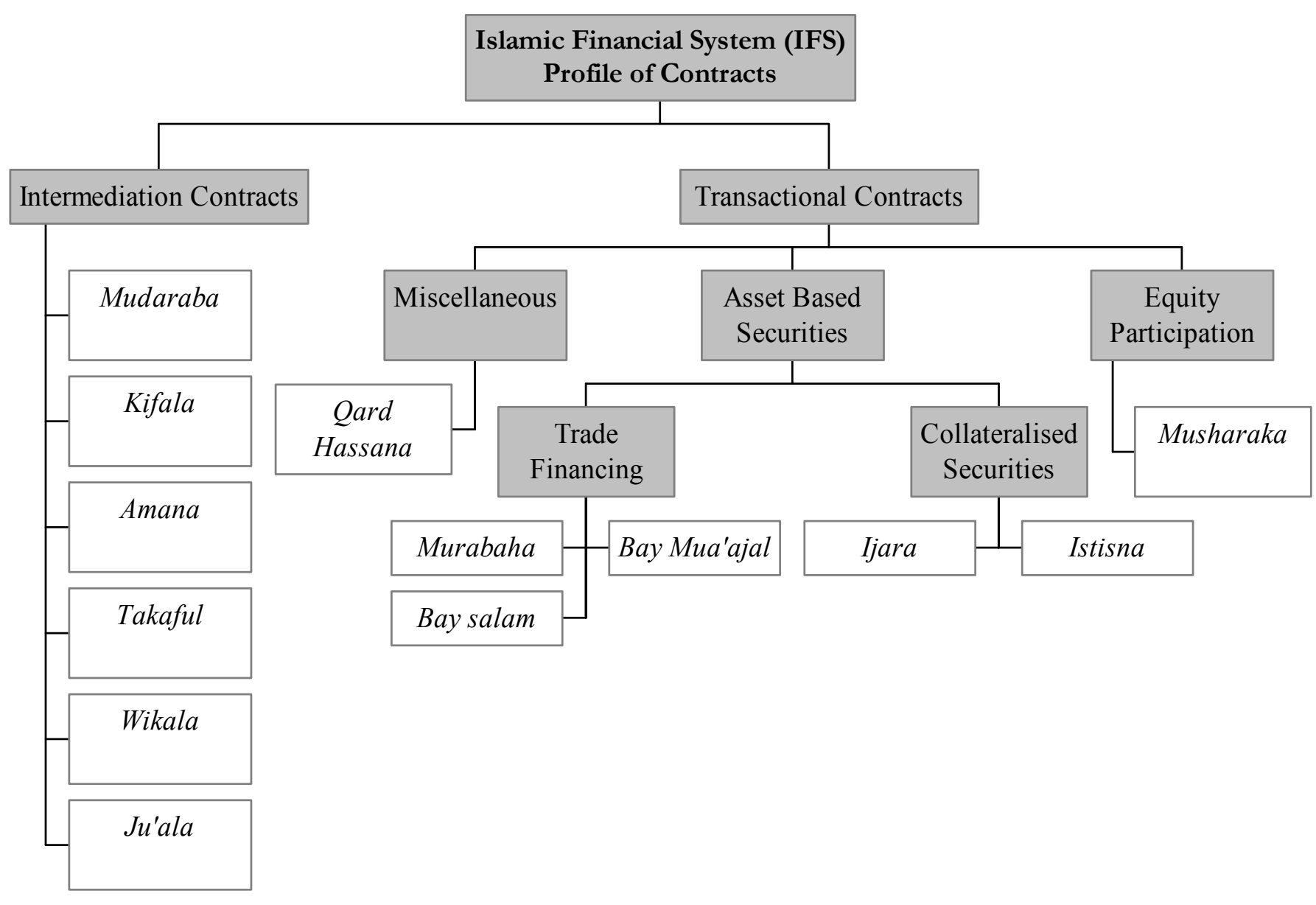

Figure 1 classifies contracts governing economic activities into transactional and intermediation contracts. Transactional contracts govern real sector transactions that include exchange, trade and the financing of economic activities. The role of intermediation contracts is to facilitate an efficient and transparent execution of transactional contracts. Transactional contracts combined with intermediation contracts offer a set of instruments with varying purposes, maturities and degrees of risk to satisfy a diverse group of economic agents. ${ }^{18}$

\footnotetext{
${ }^{18}$ Please refer to Annex I for a description of Islamic financial instruments as well as a glossary of Arabic terms used in the paper.
} 


\section{1- Transactional contracts}

The core transactional contracts are based on commodity trade based contracts like murabaha (mark-up or cost-plus), bay salam and bay mua'jal, which ultimately create instruments to provide financing of such economic transactions. It would not be an exaggeration to claim that the resultant financing techniques are somewhat similar to modern day asset-backed securities. Whereas a typical asset-backed security in the conventional system is a claim against a pool of assets, Islamic instruments are claims against individual assets. A distinct feature of such financial securities is that they resemble conventional debt securities characterized by a pre-determined pay-off with the difference that Islamic instruments are collateralized against a real asset. The result is that a financial claim is created against a real asset with a short-term maturity and relatively low risk.

Thus on one end of the risk continuum, the system offers asset-backed securities while on the other extreme the system promotes equity participation (musharaka). ${ }^{19}$ In case of musharaka, the capital owner enters into a partnership by contributing equity with others in return for sharing profits and losses at a predetermined ratio. ${ }^{20}$ The partners' contributions need not be equal, and contributions may be in the form of physical or intangible capital, such as labor, management, skill and goodwill. In between the two extremes, there are other collateralized securities originating from ijara (leasing) or istisna contracts attached to real assets, which can cater to the needs of investors looking for short to medium-term maturity. In addition to the foregoing transactional contracts, the system also offers contracts like Zakat and Qard-hassana, which are meant to promote social welfare.

\footnotetext{
${ }^{19}$ In the case of mark-up or cost-plus modes of financing, the finance user stands obligated to pay back the entire financing. The repayment by the finance user is, in fact, predetermined in advance and hence becomes a sort of debt from the finance user's point of view. For further details, see F. Khan (1994)

${ }^{20}$ In the early books of Fiqh, the partnership business has been discussed mainly under the caption of shirka. However, contemporary scholars have preferred to use the term musharaka to represent a broader concept combining features of shirka and mudaraba. Therefore, in the case of musharaka, a musharik also provides capital in addition to management skills. For further details, see Ayoub (2002).
} 


\section{2 - Intermediation contracts}

A second class of contracts are the financial intermediation ones including mudaraba, kifala, amana, takaful, ${ }^{21}$ wikala and ju'ala. In a mudaraba contract, an economic agent with capital (rabb-ul-mal) can develop a partnership with another economic agent (mudarib) who has expertise in deploying capital into real economic activities with an agreement to share the profits. Losses are borne by the capital owner only as the mudarib does not make any capital contribution. The latter may however be liable for a loss in case of misconduct or negligence on his part. However, though the capital owner is exposed to a loss of capital, he is not entitled to participate in the management of the funds, which is exclusively left to the mudarib. ${ }^{22}$

Contracts such as kifala, amana, wikala and ju'ala supplement the functions of financial intermediation. Through these contracts other functions of a financial system, such as custodial services, brokerage, consulting, guarantees and insurance, can be designed. In the case of kifala, a third party becomes surety for the payment of a debt, if unpaid by the person originally liable. It is a pledge given to a creditor that the debtor will pay the debt, fine or any other liability. In Islamic law, kifala is the creation of an additional liability with regard to the claim, not to the debt. ${ }^{23}$ The contract of $j u$ 'ala deals with offering a service for a predetermined fee or commission. A party pays another party a specified amount of money as a fee for rendering a specified service in accordance to the terms of the contract stipulated between them. The contract of Ju'ala can be utilized to offer consultations, professional services, fund placements and trust services. Ju'ala allows contracting on an object not certain to exist or to come under a party's control. It can be utilized to introduce innovative financing structures. ${ }^{24}$

\footnotetext{
${ }^{21}$ Takaful is in the nature of mutual insurance contract

${ }^{22}$ Another distinct feature of mudaraba is that the distribution of profits can only take place after the capital owner has retrieved his capital. Any intervening, possibly periodic distribution before the closing of the accounts is considered as tentative and subject to final review and revision to make good on any loss of capital. See Fadeel (2002).

${ }^{23}$ Ayoub (2002)

${ }^{24}$ Vogel and Hayes (1998)
} 
Mudaraba (a trustee finance contract) and musharaka (equity partnership) ${ }^{25}$ are the most popular contracts and are suitable for conducting financial intermediation. Both types of contracts were able to mobilize the entire reservoir of monetary resources of the medieval Islamic world for financing agriculture, crafts, manufacturing and long distance trade. $^{26}$

\section{B - Islamic Financial Intermediation: A Conceptual Framework}

The set of instruments discussed above can be used to establish a formal model for a financial intermediary operating in an Islamic Financial System. An Islamic financial institution (IFI) will perform the typical functions of financial intermediation through screening profitable projects and monitoring the performance of projects on behalf of the investors who deposit their funds with the IFI. The mudaraba contract becomes the cornerstone of financial intermediation and thus banking. Two theoretical models have been suggested for the structure of an IFI. The first model is based on mudaraba and is commonly referred to as the "two - tier mudaraba" model. The second is the "two - windows" model.

The basic concept of the "two - tier mudaraba" model is that both funds mobilization and funds utilization are on the same basis of profit sharing among the investor (depositor), the bank and the entrepreneur. The first tier mudaraba contract is between the investor and the bank, where investors act as suppliers of funds to be invested by the bank on their behalf as mudarib; the investors share in the profits earned by the bank's business related to the investors' investments. Funds are placed with the bank in an investment account. The liabilities and equity side of the bank's balance sheet thus shows the deposits accepted on a mudaraba basis. Such profit-sharing investment

\footnotetext{
${ }^{25}$ In musharaka and mudaraba, the ratio of profit distribution may differ from that of capital contribution, but the loss must be divided exactly in accordance with the ratio of capital invested by each of the partners. See Ayoub (2002).

${ }^{26}$ It is claimed that these instruments were used not only by Muslims but also by Jews and Christians to the extent that interest-bearing loans and other overly usurious practices were not in common use. See Udovitch (1981) and Chapra and Ahmed (2002)
} 
deposits are not liabilities (the capital is not guaranteed and they incur losses if the bank does so), but are a form of limited-term, non-voting equity.

The second tier represents the mudaraba contract between the bank as supplier of funds and the entrepreneurs who are seeking funds and agree to share profits with the bank according to a certain percentage stipulated in the contract. In this model, in addition to investment deposits, banks would accept demand deposits that yield no returns and are repayable on demand at par value and are treated as liabilities.

The model does not feature any specific reserve requirements on either investment or demand deposits. It has been argued that in contrast to investment deposits, demand deposits are liabilities which are not supposed to absorb any loss and therefore reserve requirement should be introduced for them. ${ }^{27}$ A distinguishing feature of the "two-tier" model is that, by design, the assets and liabilities sides of a bank's balance sheet are fully integrated and thus minimize the need for active asset/liability management, which provides stability against economic shocks.

The second model is referred to as the "two-windows" model. It also features demand and investment accounts, but takes a different view from the "two-tier" model on reserve requirements. According to the "two-windows" model, bank "liabilities" are divided into two windows: one for demand deposits (liabilities in the strict sense) and the other for investment deposits (not strictly liabilities), the choice of the window being left to the depositors. Investment deposits are used to finance risk-bearing investment projects with the depositor's full awareness. The model requires banks to hold a 100 percent reserve on the demand deposits that are guaranteed by the bank and a zero percent reserve on the investment deposits that are used by the banks to finance risk-bearing investments.

\footnotetext{
${ }^{27}$ Mirakhor (1989) and Khan (1986).
} 
On its "liabilities" side, an IFI offers current, savings, investment and special investment accounts to depositors (Figure 2). Current accounts are demand accounts and are kept with the bank on custodial arrangements and are repayable in full on demand. Current accounts are based on the principle of al-wadiah (trust or safekeeping), creating an agency contract for the purpose of protecting and safekeeping depositor's assets. The major portion of an IFI's financial "liabilities" would consist of investment accounts that are strictly not liabilities but a form of equity investment, generally based on the principle of mudaraba. ${ }^{28}$ They would be offered in different variations, often linked to a pre-agreed period of maturity, which could range from one month upward and could be withdrawn if advance notice is given to the bank. The returns are distributed between depositors and the bank according to a predetermined ratio. A distribution of 80 percent to investors and 20 percent to the bank would be typical. ${ }^{29}$

28 Particularly the case for general investment accounts.

${ }^{29}$ This ratio may vary from these numbers, however. 
Figure 2. Conceptual Balance Sheet of IFI

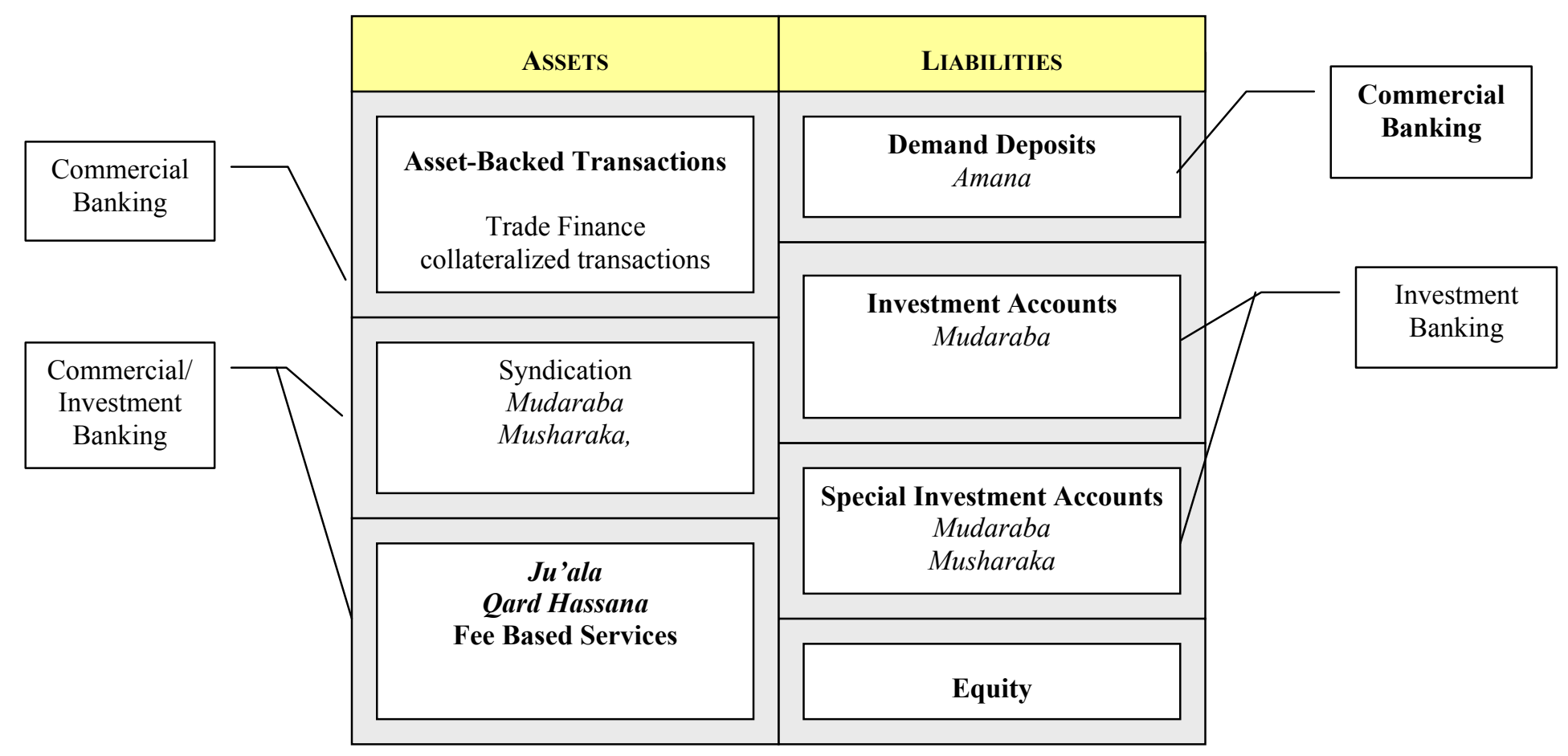

An IFI may offer special investment accounts customized for high net-worth individuals or institutional clients. These accounts also operate on the principle of mudaraba, but the modes of investment of the funds and the distribution of profits are customized to the needs of the clients. In general, special investment accounts are linked to special investment opportunities identified by the IFI. These opportunities would have specific size and maturity and result from IFI participation in a syndication, private equity, joint venture or a fund. To some extent these special investment accounts resemble specialized funds to finance different asset classes. The maturity and distribution of profits for special investment accounts are negotiated separately for each account, with the yield directly related to the success of the particular investment project. ${ }^{30}$ Special investment accounts have considerable potential for designing and developing funds with specific risk-return profiles to offer high net worth and corporate clients opportunities to manage portfolios and to perform risk management. In addition to deposits, IFI offer basic banking services, such as fund transfers, letters of credit, foreign exchange transactions and investment management and advice for a fee to retail and institutional clients.

\footnotetext{
${ }^{30}$ Lewis and Algaoud (2001).
} 
Whereas the liabilities side of an IFI offers limited modes of raising funds, the asset side can carry a more diversified portfolio of heterogeneous asset classes representing a wider spectrum of risk and maturity profile. For short-term maturity, limited-risk investments, there is a choice of asset-backed securities that resemble debt securities in terms of the payoffs. Such securities originate from trade related activities, and include murabaha, bay mua'jal, or bay salam that are arranged by the IFI which uses its skills, market knowledge as well as its customer base to finance the trading activity. In addition, an IFI can provide short-term funds to its clients to meet their working capital needs. The short-term maturity of these instruments and their backing by real assets minimize their level of risk. IFI consider these securities highly attractive and give them preference over other investment vehicles.

For the medium-term maturity investments, IFI have several choices. They can invest in ijara and istisna based assets. ${ }^{31}$ A benefit of these contracts is not only that they are backed by an asset, but they can also have either a fixed or floating rate feature, which can facilitate portfolio management. Common features of Islamic (ijara) and conventional leasing provide additional investment opportunities for IFI since investing in conventional leases with appropriate modifications can be made consistent with Shariah principles. In addition, IFI can set up special purpose (customized) portfolios to invest in a particular asset class and sector and can finance these portfolios by issuing special purpose mudarabas in the form of special investment accounts. In that sense, this segment of the asset side represents a fund of funds, each financed by matching mudaraba contracts on the liabilities side through special investment accounts. For longer-term maturity investments, IFI can engage into venture capital or private equity activities in the form of musharaka.

\footnotetext{
${ }^{31} \mathrm{~F}$. Khan (1994) points out that leasing would require a bank to deviate from its basic character as a financial intermediary, as it would require it to get involved in purchasing an asset and then keep its ownership until the asset is disposed of responsibility in terms of maintenance and associated costs over the life of the contract (at least for operating lease). Disposing of the asset requires not only bearing all risks resulting from price fluctuations, but also some marketing expertise. All this will require the bank to engage in activities beyond financial intermediation.
} 


\section{C - Islamic Financial Intermediation and Prevailing Practice}

Current practices of IFI and the composition of their balance sheets differ from the theoretical models mentioned above in four aspects. These affect the industry's evolution and the challenges it poses to regulators.

The first difference appears in the significant deviation of the structure of assets from what the theory would prescribe. On the assets side of the balance sheet, as expected a clear preference for asset-backed securities (based on trade finance) is evident. This preference is due to the fact that sale-related securities are considered low risk and resemble familiar conventional fixed-income securities in terms of the risk-return profile. In conjunction with issues related to mudaraba and musharaka, these factors make these asset backed securities the preferred choice. In addition to trade-based instruments, Islamic banks prefer leasing, considered to carry a lower risk and have less uncertain returns than musharaka or mudaraba. In a typical Islamic bank, sale and lease-based transactions dominate the assets portfolio and can exceed 80 percent, with the remainder

allocated to profit-sharing arrangements. ${ }^{32}$ As a result, IFI have limited themselves to a small set of asset classes that constrain their opportunities for portfolio diversification and its benefits. Although this practice is conservative in nature as assets are collateralized, it has associated costs in terms of additional exposure to credit and operational risk.

A second aspect of the divergence between the practice and the premises is in the choice and application of accounting policies that affect the allocation of income between shareholders and account holders or between different classes of account holders. In its essence, Islamic finance would be consistent with clear barriers in the deployment of assets between those funded by demand deposits, general investment accounts, special investment accounts and equity. However, current practice does not include such barriers, with the asset side treated as one large bucket with all stakeholders' funds comingled together. In other words, operating IFI claim to represent a hybrid of both commercial and investment banks more akin to universal banks. However, unlike

${ }^{32}$ Iqbal and Mirakhor (2002). 
conventional universal banks, IFI do not erect firewalls to separate, legally, financially and managerially, their investment and commercial banking services. ${ }^{33}$ As a result, investment accounts' funds are not "ring-fenced" from other funds, including those of equity holders. This is one of the most critical deviations in the practice of IFI and one that poses a tough challenge to regulators because different stakeholders of IFI need to be regulated under different regulating principles. Therefore, taking a one-solution-for-all approach becomes restrictive and may defeat the whole objective of regulation in this case.

A third divergence between practice and principles, related somewhat to the preceding issues, is the status of investment accounts. Although they are supposed to be operating on profit and loss principles, actual practice differs. IFI have faced the criticism that when they do write down the value of assets, they do not in practice write down the value of deposits. ${ }^{34}$ This implies that losses on the asset side are absorbed by either other deposit holders or the equity holders. This practice raises a question on the degree of transparency and information disclosure they practice. It also raises the issue of the need to separate asset types to match them closely to liabilities either through fire-walling or segmentation.

A fourth divergence stems from the governance rights granted to investment account holders. Large investment accounts serve as a source of capital to finance pools of investments and assets of the financial institution, but their holders are not granted any participation in the governance or monitoring process. ${ }^{35}$ The majority of investment account holders are individuals who may not organize themselves collectively to perform the necessary monitoring. Under such circumstances, the responsibility of regulators and Shariah boards increases to make sure that an adequate monitoring mechanism is in place to protect the rights of investment account holders.

\footnotetext{
${ }^{33}$ Karim (2001).

${ }^{34}$ Cunningham (2001).

35 Archer, Karim and Al-Deehani (1998).
} 


\section{SECTION II： ThE Risk PROFILE IN ISLAMIC FinANCIAL INTERMEDIATION}

In their intermediation function, IFI face risks that affect their ability to compete and to meet the interests of their stakeholders, namely, depositors, shareholders and regulators. A robust risk management capability, a business friendly institutional environment and an efficient regulatory framework would help Islamic banks reduce their exposure to risks, and enhance their ability to compete with conventional banks. More importantly, these elements would permit their development on the basis of the authentic foundations of Islamic financial intermediation and reap the associated benefits. This section presents an overview of the risk profile of an operating IFI with references to the theoretical model.

In the theoretical version, Islamic banks would at face value be less susceptible to instability than their conventional counterparts. This comparative advantage is rooted in the risk sharing feature where banks participate in the risks of their counter-parties, and investment depositors share the risks of the banking business. Direct market discipline is embedded in this risk-sharing principle. ${ }^{36}$ In the theoretical model, any negative shock to an Islamic bank's asset returns is absorbed by both shareholders and investment depositors. ${ }^{37}$ While depositors in the conventional system have a fixed claim on the returns to the bank's assets as they are paid a predetermined interest rate in addition to their guaranteed principal irrespective of the bank's profitability, holders of profitsharing investment accounts in the Islamic system share in the bank's profits and losses alongside the shareholders, and hence are exposed to the risk of losing all or part of their initial investment.

In prevailing practice, however, the risk-sharing advantage is "neutralized" when Islamic banks, operating in mixed systems, pay their investment account holders a competitive "market" return regardless of their actual performance and profitability. ${ }^{38} \mathrm{As}$ a result, equity holders' returns are displaced, creating for them a commercial risk.

\footnotetext{
${ }^{36}$ Market discipline is one of the three main pillars recently emphasized by the Basle Committee in enhancing the stability of the international financial market.

${ }^{37}$ See Khan \& Ahmed (2001) and Baldwin (2002).

${ }^{38}$ Baldwin (2002).
} 
Divergence of practice from the theoretical version is also reflected in shifts away from profit and loss sharing (PLS) activities, such as mudaraba \& musharaka, to other modes of financing like ijara \& murabaha. This shift likely results from risk aversion in conducting asset allocation as well as vulnerability due to liquidity on the liabilities side. The outcome is dominance in the asset portfolios of short-term, low profit and safe trade related transactions limiting the funds that can be invested in longer-term, more profitable but riskier assets.

Figure 3 presents an overview of the risk profile of an operating IFI. Risks are grouped into five broad categories: transaction, business, treasury, governance and systemic risks. While these categories are also applicable to conventional finance, specific risks within them are more relevant to IFI, their balance sheets' profile and the nature of contracts they use (see Annex II for a description of the different risks and their impact on different stakeholders ). 


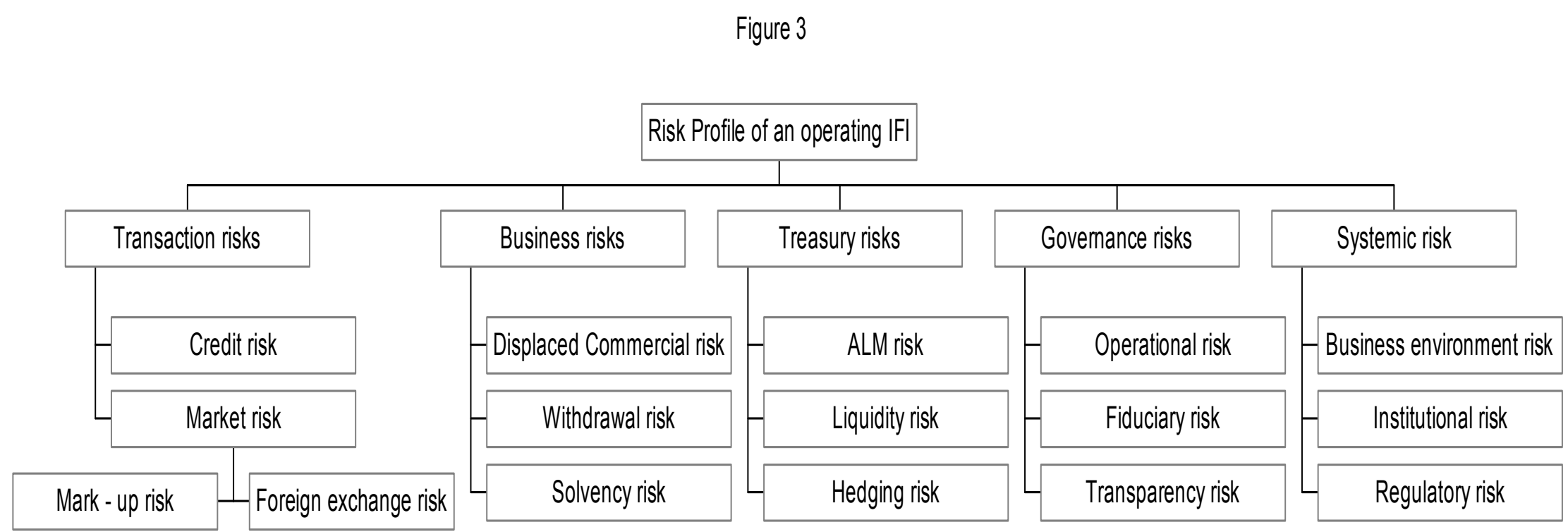


It has been argued that the PLS feature of Islamic finance introduces additional risks to the industry. Specifically, displaced commercial risk has been identified by AAOIFI (1999) as the risk arising when an Islamic bank is under the pressure of paying its investment depositors a rate of return higher than what should be payable under the "actual" terms of the investment contract. An Islamic bank engages in such self-imposed practice to induce its investment account holders not to withdraw their funds in the bank to invest them elsewhere. As a result, during bad times the bank may forgo part or all of its shareholders' profits, and this may adversely affect its own capital. An example is the International Islamic Bank for Investment \& Development in Egypt, which distributed all of its profits to investment account holders while the shareholders received nothing from the mid to late 1980 s. $^{39}$

"Withdrawal risk" is at the other end of the spectrum of business risks. It mainly results from the competitive pressures an IFI faces from existing Islamic or conventional counterparts. An Islamic bank could be exposed to the risk of withdrawals by its depositors as a result of the lower rate of return they would receive compared to what its competitors pay. ${ }^{40}$ Such withdrawals would erode the franchise value of the bank. Another type of business risk is solvency risk, which is the risk that a bank has insufficient capital to continue operations. ${ }^{41}$

Fiduciary risk has a specific nature in the case of IFI as it directly emanates from the PLS feature of Islamic finance. AAOIFI (1999) defines fiduciary risk as that of becoming legally liable for a breach of the investment contract either for non-compliance with Shariah rules or for mismanagement of investors' funds. Such legal liability would expose the bank to direct losses associated with breach of its fiduciary responsibility toward its depositors as well as indirect losses resulting from the decline in the market price of its listed shares. ${ }^{42}$

\footnotetext{
${ }^{39}$ In 1988, the bank distributed to its depositors an amount exceeding its profits, and the difference appeared in the bank's accounts as "loss carried forward". It is also reported that this bank was subject to temporary takeover by the Central Bank of Egypt; see Warde (2000).

${ }^{40}$ Khan \& Ahmed (2001).

${ }^{41}$ See Greuning \& Bratanovic (2003).

${ }^{42}$ The latter effect should impose indirect market discipline on Islamic banks, as will be discussed in the next section.
} 
In addition, the reputation of the bank would be adversely affected by negligence or misconduct. Even a financially sound Islamic bank could be exposed to the risk of failure as a result of losing the confidence of its depositors, who would withdraw their funds. ${ }^{43}$ Fiduciary risk also exposes both equity holders and investment depositors to risk of economic losses as they would not receive their potential profit share as a result of the bank's misconduct. ${ }^{44}$

In this context, information disclosure facilitates market discipline and enables different stakeholders to protect their own interests by allowing depositors to withdraw their funds, shareholders to sell their shares and regulators to take the necessary actions in case of any mismanagement or misconduct. However, the current differences in accounting treatment between Islamic banks have reduced the comparability, consistency and transparency of their financial statements. ${ }^{45}$ This creates uncertainty and limits the potential role of market discipline. The Basle Committee defines transparency as "the public disclosure of reliable and timely information that enables users of that information to make an accurate assessment of a bank's financial condition and performance, business activities, risk profile and risk management practices". ${ }^{46}$ Accordingly, lack of transparency creates a risk of incurring losses due to bad decisions based on incomplete or inaccurate Information.

A related type of governance risk is operational risk defined as the risk of failure of internal processes as related to people and systems. Specifically, people risk, arising from incompetence or fraud, ${ }^{47}$ exposes Islamic banks to potential losses. For instance, an internal control problem cost the Dubai Islamic Bank \$50 million in 1998 when a bank official did not conform to the bank's credit terms. This also resulted in a run on deposits in the magnitude of $\$ 138$ million, 7\% of the bank's total deposits, in just one day. ${ }^{48}$ This is in addition to technology risk, another type of operational risk, which is associated with

\footnotetext{
${ }^{43}$ Ali (2002).

${ }^{44}$ For instance, any profits accrued to the bank as a result of investment in non-Shariah acceptable assets would be distributed for charity purposes.

${ }^{45}$ Archer \& Ahmed (2003).

${ }^{46}$ Basle Committee on Banking Supervision (September 1998).

${ }^{47}$ Khan \& Ahmed (2001).

${ }^{48}$ Warde (2000).
} 
the use of software and telecommunication systems that are not specifically tailored to the needs of Islamic banks. ${ }^{49}$

Equally important for the operation of Islamic as well as conventional banks is the presence of a conducive institutional environment and an efficient regulatory framework. Such poor supporting institutional infrastructure exposes Islamic banks to systemic risks related to institutional, legal and regulatory issues. At the forefront of these is institutional risk resulting from the lack of consensus among Fiqh scholars on contractual rules governing financial transactions. For instance, while some Fiqh scholars consider the terms of a murabaha or istisna contract to be binding to the buyer, others argue that the buyer has the option to rescind from the contract even after making an order and paying the commitment fee. ${ }^{50}$ This raises Islamic banks' exposure to counter-party risks arising from the unsettled nature of contracts, and may lead to potential litigation problems. A related issue is the general confusion created by the heterogeneous interpretations of the fundamental Shariah rules resulting in differences in financial reporting, auditing and accounting treatments by Islamic banks. ${ }^{51}$

Moreover, the lack of standardized contracts for Islamic financial instruments as well as the absence of effective litigation and dispute resolution systems create a business environment risk. Poor enforceability of contractual agreements ultimately increases Islamic banks' exposure to counter-party risks of default and delinquency. ${ }^{52}$ While the imposition of penalty in the case of late payment is not accepted according to Shariah law, some banks enforce the penalty as a deterrent mechanism and use the collected sums for charitable causes. ${ }^{53}$

\footnotetext{
${ }^{49}$ Khan \& Ahmed (2001).

${ }^{50}$ Khan \& Ahmed (2001)

${ }^{51}$ As previously discussed, this results in lack of transparency and comparability in their financial statements; see Archer \& Ahmed (2003).

${ }^{52}$ Khan \& Ahmed (2001).

${ }^{53}$ Archer \& Ahmed (2003).
} 
Negligence or mistakes in complying with regulations do expose banks to regulatory risk and may lead to penalties. Such risk may however result from a high degree of discretion on the part of the supervisor or from limited transparency in the regulation. ${ }^{54}$ Confusion may also result in regulatory risk where Islamic banks are subject to dual regulation in countries with mixed systems of Islamic and conventional banking. In addition, differences between the supervisory Shariah boards ${ }^{55}$ (SSB) of individual IFI within each country as well as differences between the regulatory bodies in various countries may create general uncertainty as to the rules to be followed.

Treasury management function is a challenging task affecting the performance of Islamic banks, which are particularly vulnerable to liquidity risk given their limited opportunities to access funds to meet their obligations. Such risk results from the mismatch between the maturities of the two sides of the balance sheet, creating either a surplus of cash that needs to be invested or a shortage of cash that needs to be funded. ${ }^{56}$ Prohibition by Shariah law from borrowing as well as the absence of an active inter-bank money market have restricted Islamic banks' options to efficiently manage their liquidity position. The current use of secured commodity murabaha and short-term trade financing has enabled Islamic banks to invest their short-term surplus cash. ${ }^{57}$ However, Islamic banks do not have an efficient mechanism for funding their shortage of cash in case of need. ${ }^{58}$

These factors have raised Islamic banks' exposure to liquidity risk, and adversely affected their profitability by limiting their ability to invest their capital in long-term, generally less liquid but more profitable assets in order to honor withdrawal requests from their depositors. According to Maroun (2002), factors such as lack of Shariah

\footnotetext{
${ }^{54}$ Khan \& Ahmed (2001).

${ }^{55} \mathrm{SSB}$ is considered to be the governance body within each IFI, and it is responsible for approving the Shariah compliance of contracts as well as monitoring their proper implementation; see Archer \& Ahmed (2003).

${ }^{56}$ Maroun (2002).

${ }^{57}$ It is estimated that IFIs have $\$ 20$ to 30 billion available for short-term investment; Ali (2002).

${ }^{58}$ Secured commodity murabaha involves the purchase of commodities, traded on the London Metal Exchange, with the full payment of the spot price. This is followed by their sale to a third party on the basis of murabaha for a deferred payment with a maturity of one week to six months with spot delivery. Repayment of the principal and profit is usually guaranteed by an acceptable international bank. Short-term trade financing is similar to secured commodity murabaha except for the fact that it is mainly used to finance the importation of basic commodities needed locally, such as crude oil. See Maroun (2002).
} 
compatible instruments, the absence of qualified market makers and the limited dissemination of information and data hinder the development of well-functioning secondary markets where long-term instruments can be traded. For instance, long-term mudaraba investment certificates can provide liquidity for both the bank and the investor by enabling the latter to trade the certificates in the secondary market without the need to redeem them directly with the issuing bank. ${ }^{59}$ In this respect, the establishment of the International Islamic Financial Market (IIFM) and the Liquidity Management Center (LMC) should permit a more efficient management of IFIs' liquidity needs.

Islamic banks are also exposed to credit risk. It is a counter-party risk inherent in some modes of Islamic finance. Exposure to such risk is increased by the absence of well developed credit risk assessment systems and associated expertise for Islamic banks. For instance, counter-party risk arises when an Islamic bank makes payment in a bay mua'ajal contract, or delivers assets in a murabaha deal before receiving payment, hence being exposed to potential loss. In bay salam or istisna contracts, the bank is exposed to the risk of failure to supply on time or at all, or failure to supply the quality of goods as contractually specified. There may also be other related price risks, such as inventory storage costs associated with the nature of salam agricultural-based contracts. ${ }^{60}$

In PLS activities, use of mudaraba on the assets side of the balance sheet gives rise to moral hazard problems. While rabb-ul-mal (IFI) bears all the losses in case of a negative outcome, IFI cannot oblige users of the funds (mudarib) to take the appropriate action or exert the required level of effort needed to generate the expected level of returns. Such situations can be exploited by users of IFI's funds. ${ }^{61}$ Also, the bank does not have the right to monitor or to participate in management of the project and hence may loose its principal investment in addition to its potential profit share if the entrepreneur's books show a loss. ${ }^{62}$

\footnotetext{
${ }^{59}$ As a result of these constraints, most transactions take place in the primary market with limited trading in the secondary market. Ijara sukuk, issued by the Bahrain Monetary Authority (BMA), present an exception for which a secondary market exists. They are traded on the Bahrain Stock Exchange. See Maroun (2002).

${ }^{60}$ Khan \& Ahmed (2001).

${ }^{61}$ Lewis \& Algaoud (2002).

${ }^{62}$ Errico \& Farahbaksh (1998).
} 
Mudaraba can also expose an Islamic bank to principal-agent problems where the bank enters into the mudaraba contract as rabb-ul-mal or principal, and the mudarib is the agent. The user of the funds (mudarib) may have incentives to expand the expenditures on the projects and to increase the consumption of non-pecuniary benefits at the expense of pecuniary returns since the increased consumption is partly borne by the bank while the benefits are entirely consumed by the entrepreneur. A similar problem arises on the liabilities side, where investment account holders place their money with IFI on a mudaraba basis. ${ }^{63}$

The moral hazard problem would be reduced in musharaka where the capital of the partner (musharik) will also be at stake. Furthermore, equity partnership would minimize the problem of informational asymmetry as the IFI would have the right to participate in the management of project in which it is investing. ${ }^{64}$ However, the musharaka asset class has an associated cost in the form of adverse selection and therefore requires extensive screening, information-gathering and monitoring. Each musharaka contract would require careful analysis and negotiation of PLS arrangements leading to higher cost of intermediation for an IFI. ${ }^{65}$ As a result of the problems associated with mudaraba and musharaka, IFI would tend to allocate limited funds to these asset classes. This implies an increased reliance on asset-backed securities limiting IFI's choice of investment, and may ultimately hamper their ability to efficiently manage risks and diversify their portfolio.

Islamic banks face a market risk regarding notably murabaha contracts. Movements in the underlying benchmark interest rate alter the value of the murabaha contract held by the bank. ${ }^{66}$ Islamic banks are exposed to such risk as their mark-up rate

\footnotetext{
${ }^{63}$ This gives rise to fiduciary risk as previously discussed.

${ }^{64}$ Khan (1994) claims that IFI is able to invest in large enterprises because the users of the funds owning large stakes in the business would not put the banks in a disadvantageous position in terms of risk, which may reduce overall risk and thus improve the profitability of the bank.

${ }^{65} \mathrm{Sadr}$ and Iqbal (2000) provide empirical evidence that increased monitoring resulted in an increase in the portfolio size of musharaka contracts on the assets side of the balance sheet of an IFI. Additional monitoring recovered its costs in higher returns.

${ }^{66}$ They often use the underlying market interest rate, usually the LIBOR, as a benchmark to price their financing facilities; specifically, murabaha.
} 
is held fixed for the duration of the contract while the benchmark rate changes. ${ }^{67}$ Foreign exchange rate movement is another transaction risk arising from the deferred-trading nature of some contracts offered by Islamic banks as the value of the currency in which receivables are due may depreciate or the currency in which payables are due may appreciate. $^{68}$

Efficient risk management capacity is necessary to enable Islamic banks to strategically position themselves in the global market by reducing their overall risk exposure. The absence of robust risk management systems may deprive Islamic banks from the ability to hedge risks, and could undermine their potential contribution. Adequate resources need to be devoted to risk identification and measurement as well as the development of risk management techniques. In this respect, there is a pressing need to combine solid understanding of Shariah law with strong knowledge of modern risk management techniques to be able to develop innovative risk mitigation and hedging instruments.

\section{SECTION III: ThE REgulation OF ISLAMIC FinANCE}

On the basis of the foregoing review of the nature of Islamic financial intermediation as well as the risks faced by IFI and the financial system in which they operate, the following considers the regulatory framework the industry would need. This is done by considering sequentially the current legal and regulatory framework governing IFI, the rationale for regulation, the regulatory options and necessary conditions for effective regulation.

\section{A- Current Legal and Regulatory Practice}

The legal and regulatory practice governing Islamic banks varies across countries. ${ }^{69}$ Indonesia, Iran, Malaysia, Pakistan, Sudan, Turkey, U.A.E and Yemen have enacted Islamic banking laws. However, these laws may not always fully take into

\footnotetext{
${ }^{67}$ See Baldwin (2002), Khan \& Ahmed (2001) and El Gary (2000).

${ }^{68}$ Khan (2001).

${ }^{69}$ See Archer and Ahmed (2003).
} 
account unique characteristics of Islamic banking. For example, the Malaysian Islamic Banking Act (1993) refers to banking as a "lending business" and investment accounts are considered to be liabilities. In Iran, Islamic banks accept customer investments on the basis of the wikala contract, an agency contract, not the mudaraba contract, as is the case in other countries. ${ }^{70}$ In some of the other Muslim countries, such as Saudi Arabia and Egypt, no laws have been enacted to regulate Islamic banks. They therefore operate under the same laws governing conventional banks. Kuwait's sole IFI is licensed as a finance house, not a bank, and is supervised by the Ministry of Commerce rather than the Central Bank.

Greater attention has been paid since the early 1990s to the regulatory and supervisory frameworks governing IFI. Differences between balance sheet structures of Islamic and conventional banks and the features of Islamic financial contracts have been recognized to have important implications for accounting and financial reporting. ${ }^{71}$ Early studies raising the issues of regulation and supervision of IFI include Archer and Karim (1997), Archer, Karim and Al-Deehani (1998), and Errico and Farabakash (1998). ${ }^{72}$ These studies note that an appropriate regulatory framework needs to place greater emphasis on accounting standards and information disclosure. Errico and Farabakash (1998) suggest a supervisory framework based on the standards and best practices established by the Basle Committee, and an Islamic finance-tailored prudential framework based on the CAMEL system. Errico and Sundarajan (2002) reinforce this view by recommending a regulatory framework created along the same lines as a CAMEL framework and the adoption of an SEC-type disclosure system. AAOIFI has promulgated a Statement on the Purpose and Calculations of Capital Adequacy Ratio (CAR) for Islamic Banks, which takes into account differences between deposit accounts in conventional banking and investment accounts in Islamic banking. ${ }^{73}$ This statement

\footnotetext{
${ }^{70}$ The wikala contract operates on the basis of the agent receiving a fixed fee, not a share of profits like in the mudaraba.

${ }^{71}$ See AAOIFI (1999) and Archer \& Ahmed (2003).

${ }^{72}$ A number of other studies have been prepared since then, many quoted in this paper.

73 See also Mulajawan, Dar \& Hall (2002) for a discussion of the issue and a suggestion for a modified CAR.
} 
builds on the capital adequacy principles laid down by the Basel Committee. ${ }^{74}$ Archer and Ahmeds (2003) point out features of Islamic finance that require specific accounting, corporate governance and prudential regulations. They note issues regarding the applicability of the IAS to IFI and further describe efforts undertaken notably by AAOIFI in creating accounting and auditing regulations, standardizing Shariah interpretations and establishing capital adequacy ratios for IFI.

In November 2002, a group of central banks from Islamic countries established in Kuala Lumpur the Islamic Financial Services Board (IFSB). The purpose of the IFSB is to develop international standards relevant to the IFI including corporate governance, transparency and disclosure. With the IFSB, AAOIFI and the Islamic rating agency as well as the various national efforts at providing a framework governing Islamic financial intermediation, the essential building blocks for the formulation and implementation of public policy are coming into place. Exploiting the synergies between these initiatives will be essential for a growing industry consolidating its credentials.

\section{B - Why Financial Regulation}

Considering the theoretical models of either the "two-tier mudaraba" or "twowindows", and conventional rationales for regulation, this paper argues in the following that it is reasonable to propose minimal regulation of IFI operating according to the core risk sharing principles. However, prevailing practice of Islamic finance appears to present risks akin to those in conventional banking and would require a similar regulatory framework. In reaching these views, the paper proceeds by first outlining rationales for regulation. It is believed that clarity on the rationale for regulation is an important prerequisite to avoid either over-regulating and stifling business activity, or underregulating and leaving too much room for risk-taking in the pursuit of profitability.

\footnotetext{
${ }^{74}$ See also Chapra \& Khan (2000) and Mulajawan, Dar, and Hall (2002).
} 
There are diverse views on the need for regulation in conventional finance. They range from positions of almost total opposition to any regulation, ${ }^{75}$ to the justification of broad, intrusive regulation. These positions reflect varying views on different rationales for regulation, in particular: i) the supply of a public good; ii) the protection of public resources, or iii) the enhancement of the integrity of fiduciary contracts. Islamic finance has been subject to a similar diversity of views. For example El Sheikkh (2000) mentions, among others, "the widely held view by Islamic jurists ... that Islamic banks should not be regulated or supervised by any authority" ${ }^{76}$

While acknowledging the latter view, Chapra and Khan (2000) argue the need for regulation. In the following, the paper contrasts prevailing rationales for regulation with various arguments made notably by Chapra and Khan (2000) for the regulation of IFI. The paper considers sequentially the public good, protection of depositors and integrity of fiduciary contracts views of regulation, and then assesses their relevance to IFI.

(1) Public Good View. In conventional finance, one view is that regulation provides a public good that the market cannot supply on its own. This perspective would proceed from two premises. A first one is that the objective of prudential regulation is the mitigation of risks taken by stakeholders (e.g., depositors) unable to undertake on their own the necessary due diligence to assess these risks. In practice, it is the inability of a majority of depositors to assess the quality of the contract they enter into when they decide to place their resources with a financial institution. Some stakeholders have sufficient investment savvy to develop these assessments on their own and would not in principle need, in the same degree, the support of public regulation, except for transparency and disclosure requirements necessary to conduct their due diligence.

\footnotetext{
${ }^{75}$ Rodriguez (2002).

${ }^{76}$ El Sheikkh (2000).
} 
A second premise of the public good approach is that the objective of prudential regulation is the mitigation of risks of disruption of the normal business performed by the financial system in terms of payments or the provision of liquidity. Such systemic risks could be the outcome of a spillover from distress in one institution unable to honor its commitments, undermining the confidence in the system. It could also be the result of a failure in the payments system itself, whether its material infrastructure or the mechanisms and instruments to exchange liquidity.

From the foregoing, public prudential regulation supplies two types of public services: a) the mitigation of the risks faced by the stakeholders needing protection, in various degrees, and b) the mitigation of the risks that could lead to dangerous systemic disruptions and contagion. Consequently, from the public good perspective, prudential regulation would call for a clear sense of the type, quality and quantity of the public good to be delivered, as well as the nature of the risks and risk exposure or values at risk involved.

(2) Protection of Public Resources View. Another conventional finance view of financial regulation is that the existence of an explicit or implicit safety net, notably in the form of deposit insurance, creates a government contingent liability. The existence of such a commitment of public resources would entail not only the right, but also the duty of the public authority to regulate activities whose performance may endanger these resources. This view is not unrelated to the public good perspective as the existence of deposit insurance is itself a public service.

(3) Integrity of Fiduciary Contracts. Another perspective on regulation is provided by a focus on the fiduciary nature of the business of finance. The role of regulation is seen here as the provision of sufficient checks and bounds to mitigate the risks of the intermediary failing the trust of its stakeholders. These are generally seen as the depositors, but also include small shareholders, raising the importance of corporate governance. 
Four reasons presented by Chapra and Khan (2000) for the regulation of IFI are discussed in light of the foregoing three views on the rationale for regulation.

a) Systemic considerations, particularly the need to maintain an orderly payments system and ensure the development of the economy.

- The promotion of orderly payments is clearly in the nature of a public good and consistent with this rationale for financial regulation. Whether in the theoretical model of an IFI or in current practice, regulation is likely to be required to mitigate the risks of disruption in payments.

- The promotion of economic development may be beyond the role that should be assigned to financial regulation. The latter can promote trust in the financial system, encourage more intermediation and diminish the risk of failure, all elements that would encourage activity expansion. However the design of financial regulation to directly promote development may distort its objectives of ensuring soundness and stability and pose difficult challenges for regulators having to choose between promoting economic development and ensuring the stability of the financial system.

b) Protecting the interest of demand depositors. In terms of a theoretical IFI model, the case for introducing regulation to protect depositors is less compelling than in conventional finance. This view seems to underlie the "two-tier mudaraba" model that does not envisage any reserve requirement. The essence of Islamic financial intermediation being symmetrical risk as well as profit and loss sharing, introducing a guarantee on the downside would run counter to the core objective. Investment depositors should however expect to be informed on the features of the contract they enter into and have a recourse if it is breached. Hence regulation promoting the integrity of fiduciary contracts would be consistent with the 
theoretical IFI model. ${ }^{77}$ With existing IFI, depositors may not always be fully apprised on the risks they face in principle with their deposits while at the same time IFI try to protect their deposit base by providing sufficient security assurance and returns. In this case, there is a case for regulation that seeks to protect depositors, public resources and fiduciary contract integrity. The protection of demand depositors is envisaged in the "two-windows" model and can be justified through either of the three perspectives considered in this paper.

c) Ensuring compliance with Shariah. The relationship between civil and religious law varies across national jurisdictions. In the case where there is an orientation toward a strong separation, it would be difficult to justify assigning to public authorities the role of ensuring that banking activities comply with Shariah. This would be considered a private religious matter that does not call for public intervention. The issue of truth in disclosure and in advertisement would however remain and would allow stakeholders to have a recourse. This would not however be a matter of financial regulation, but one of broad institutional infrastructure for business. In jurisdictions where the distinction between civil and religious law is less pronounced, one can well see a public policy choice for assigning to a public regulator the role of ensuring that banking activity complies with Shariah.

d) Supporting the integration of IFI in the international financial system. Integration would develop from the participation of IFI in the financing of international trade and international payments. Counterparts of IFI would want to be satisfied of the ability and commitment of IFI to fulfill the contracts they enter into. In this respect national and international regulation can be founded on the public good need to ensure orderly participation in international payments and the integrity of fiduciary contracts.

\footnotetext{
${ }^{77}$ The protection of demand depositors, e.g., amana deposits, and their role in payments could call for some regulation, however. At the same time, it raises the issue of the nature of the business in which the institution is engaged.
} 


\section{C - Regulatory Options}

Regulators have traditionally governed their jurisdictions through direct rules mostly on capital, assets and income allocations. ${ }^{78}$ At the same time, regulatory changes often lag financial developments and may consequently either constrain the ability of financial institutions to flexibly manage their portfolios, or provide them with opportunities to take unchecked risks implicitly comforted by the existing safety net. ${ }^{79}$ In adapting to these developments, the profession is now moving toward letting regulated institutions assess and manage their risks within a framework agreed on with the regulator. ${ }^{80}$ In this context, numerous voices call for the introduction of mechanisms to let the market impose the needed discipline on financial intermediaries, ${ }^{81}$ while others have questioned the applicability and effectiveness of such market reliant approaches. ${ }^{82}$

In light of the foregoing, two sets of issues face regulators of IFI, once they have clarified the rationale for the introduction of regulation. These issues relate first to the type of regulation needed and second to the method of regulation. In terms of type of regulation, one can consider issues such as capital, transparency or licensing requirements. The method of regulation can rely in various degrees on direct "command and control" rules, on market discipline (direct and/or indirect) or institution home developed risk assessments. The type and method of regulation chosen will depend on the rationale for regulation adopted and on the type of IFI considered, be it a model Islamic financial intermediary or in line with prevailing practice.

\footnotetext{
${ }^{78}$ This is described as "the increasingly ineffective command-and-control regulations" in Chami, Khan, and Sharma (2003).

${ }^{79}$ MacLachlan (2001).

${ }^{80}$ See notably Basel Committee On Banking Supervision (BCBS) (2003).

${ }^{81}$ See Calomiris (1999) and Evanoff \& Wall (2000). The essence of market discipline is to induce market investors to penalize excessive risk-taking by raising funding cost and limiting its availability. This can happen directly with depositors demanding higher returns or withdrawing their deposits. It can happen indirectly if there is an asset traded in the market whose price promptly reflects investors' assessments of the risks that the institution that has issued them is taking.

${ }^{82}$ Basel Committee On Banking Supervision (BCBS) (2003), Bliss (2001) and Karacadag \& Shrivastava (2000).
} 
(1) In a theoretical IFI model, minimal regulation is expected with less emphasis on capital requirements, more on transparency and disclosure, probably more on screening management profile and business line in licensing, and equivalent in supervision as compared to conventional banking. There would be also an expectation of larger reliance on direct market discipline and less on "command and control regulation".

Theoretical IFI models developed to date could be either the "two-tier mudaraba" or "two-window" type, in essence using mostly PLS accounts on both sides of the balance sheets. They would provide trade finance or facilitation as well as payments services. They would take amana deposits as part of these services. The PLS intermediation has direct market discipline embedded in it and hence should not lead to a capital requirement. Some minimal capital may be needed for protecting the reputation of the institution, that is its legitimacy as a partner for all its stakeholders. ${ }^{83}$ But one could argue that sufficient transparency and disclosure should allow markets to judge this legitimacy and induce the institution on its own volition to maintain the needed level of capital. The case for a capital requirement to protect orderly payments and amana deposits would be stronger. It is not likely to lead to the same capital requirement and would suggest the need to consider the appropriateness of bundling the intermediation and payments services in the same balance sheet. Consequently, the regulation of a theoretical IFI would need to put a heavy emphasis on transparency and disclosure as well as licensing requirements, but de-emphasize a capital requirement.

(2) In an existing IFI, prevailing intermediation practices would seem to point to the need for equivalent emphasis on a capital requirement, supervision and licensing, and a larger one on transparency and disclosure, compared to conventional banks. ${ }^{84}$ Competitive pressure is inducing IFI in the market to provide sufficient safety and return to depositors in unrestricted investment accounts. They consequently face the risk of "displacing" shareholders in their returns and capital to accommodate these depositors.

\footnotetext{
${ }^{83}$ This would deal with Chapra's and Khan's point on the acceptance of IFI as members of the international financial system, sometimes also referred to as international integration.

${ }^{84}$ In conventional banks that offer a window for Islamic services, there may be opportunities for regulatory arbitrage that would also call for transparency and disclosure.
} 
As a result they are practically facing a similar intermediation risk to conventional banks and should therefore be subject to similar capital and supervision requirements. The pooling of amana, unrestricted investment deposits and capital in funding their assets raises transparency issues for the distribution of returns or losses. It consequently calls for rigorous transparency and disclosure requirements. It would also call for significant scrutiny in licensing, notably with respect to managers' profiles.

\section{D - Requisites for Effective Regulation}

Effective regulation requires readable, reliable signals of the risks that a financial institution faces resulting from its own behavior or from events external to it, as well as risks that may affect the financial system through contagion, or infrastructure failure. It also requires an ability to process these readable signals and to introduce the appropriate corrective actions as needed. As such it may be more akin to sophisticated art that uses advanced techniques. ${ }^{85}$ But even if art presumes independence and creativity, beyond the availability of a good technique, it still requires the necessary tools.

In this respect the role of the broader institutional infrastructure is core. Of particular importance would be the clarity and enforceability of property rights, the quality of contract law and opportunity to bring prompt remedies to breaches, the efficiency of judicial recourse and other dispute resolution mechanisms. The majority of existing IFI operate however in jurisdictions where there is much left to be desired in these matters, which adversely affects their development.

More closely related to finance, the quality and transparency of accounting and auditing play a crucial role. Measurement and comparison of risk exposure should underlie regulation. The efforts at establishing accounting and auditing standards for IFI have made a significant contribution in this respect. However, disclosure of accounting results may not be an adequate instrument for risk assessment because, as a structure,

\footnotetext{
${ }^{85}$ Although dealing with the Federal Reserve policies and not regulation per se, Woodward's title of his book on A. Greenspan, "The Maestro," is indicative of this aspect.
} 
accounting is directed toward value, not risk allocation. ${ }^{86}$ This situation gives additional importance to other services, such as the collection and dissemination of financially relevant information and credit rating. In addition it would call for renewed efforts at enhancing the relevance of accounting and auditing for risk assessment.

With financial innovation, including through IFI, various instruments and structures are emerging to meet the demand for specific services. As a result, the functions of financial institutions are evolving continuously. Such increased fluidity of the objects of regulation calls for nimbleness and skills on the part of the regulator with a frequent assessment of the adequacy of their perspective. ${ }^{87}$

\section{SECTION IV: A VISION FOR THE ISLAMIC FINANCE INDUSTRY}

The combination of services offered by operating IFI and the prevailing practices they follow compound the difficulties of designing a regulatory framework to govern them. First, the problem of co-mingled funds from different classes of deposit holders needs to be addressed. One approach could be to encourage IFI to structure their operations in clearly defined and separated segments catering to different classes of depositors depending on their respective investment objectives. For example, one class of depositors may be looking for custodial services only, while the others may need to place funds for performing day to day transactions and therefore would not exhibit any risk appetite. Similarly, there may be a class of depositors that is less risk averse and therefore would like IFI to deploy its savings for longer term.

Therefore, a vision consistent with principles could see an IFI structured as a group of fairly independent entities, each designed to optimize the functional demands of its clients. This view is elaborated in figure 4 , which shows three distinct segments.

\footnotetext{
${ }^{86}$ Merton (1995).

${ }^{87}$ For example, Merton (1995) suggests considering a functional rather than an institutional perspective for regulation to enhance the ability of regulators to follow market developments.
} 
Figure 4. Segmented Approach to IFI Regulations

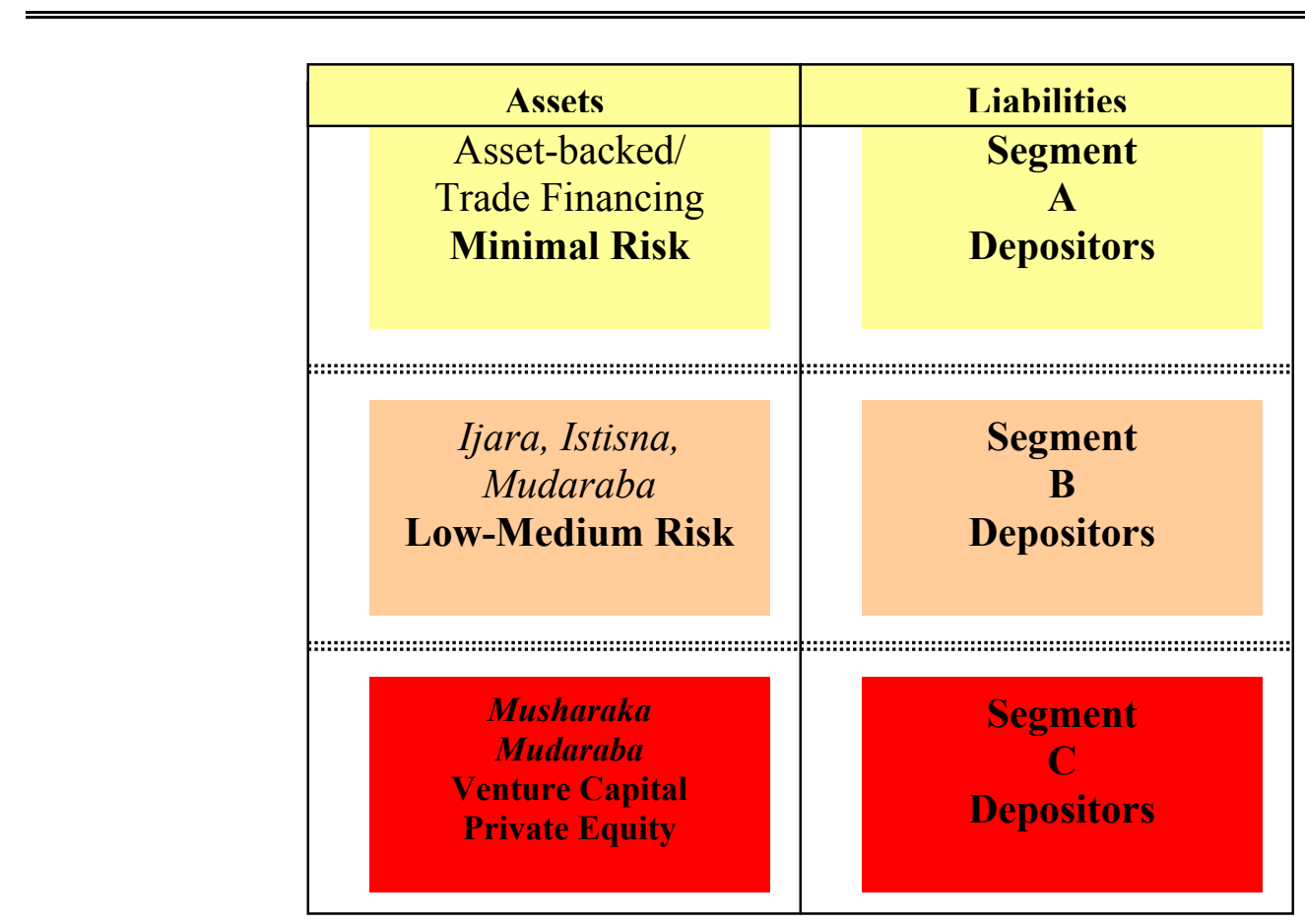

$\underline{\text { Segment A }}$ is designed to handle funds for depositors who are highly risk averse and require a high level of liquidity and would use the funds for daily transactions or would prefer to keep savings in safe assets where their capital (principal) is preserved. This segment will invest funds in asset-backed securities with fixed-income characteristics and IFI will intermediate by screening and monitoring such opportunities and making sure that credit and operational risk are contained. The concept is similar to narrow banking and would require a similar approach to its regulation.

$\underline{\text { Segment B }}$ is designed to cater to depositors with the next level of risk appetite who are willing to take some risk in expectation for a higher return, with capital preservation and liquidity less high on their agenda. IFI would deploy these funds in medium- to long-term instruments, such as ijara or istisna, or may prefer to invest on mudaraba basis directly with the entrepreneur or through mudaraba certificates. If there is a well developed secondary market for mudaraba based funding, then the form of intermediation taken by IFI will be very similar to mutual funds where IFI will manage and invest depositor's money in different mudaraba funds. Since the contractual 
agreement with the depositors would be similar to the fiduciary responsibility of a mutual fund in a conventional system, the same regulatory principles would apply.

$\underline{\text { Segment } \mathrm{C}}$ is designed for investors who would be willing to take additional risk and would like to participate in riskier investments, like private equity or venture capital. IFI could deploy these funds on the basis of musharaka or mudaraba instruments. When funds are invested on musharaka basis, the IFI also gains rights to participate in the governance of the enterprise, which raises another issue for regulators. The IFI as equity participant becomes an institutional investor that has a vested interest in the governance of the institutions, the recipients of funds. This implies that the financial institution itself becomes a stakeholder in the enterprises that depend on funds it provides. Since Islamic financial principles advocate a stakeholder approach to corporate governance, the IFI would be expected to conduct active monitoring of enterprises it invests in. In these circumstances, the IFI would behave in a similar way to financial institutions in a bankbased or insider system practiced in Germany or Japan. It would be expected that a representative of IFI participate in supervisory boards of enterprises in which they have considerable investment and a long-term relationship. The IFI's relationship with musharaka enterprises would be of long-term nature with active involvement in governance in contrast to a short-term, transactional relationship.

To summarize, an IFI structured to provide financial intermediation through clearly segmented windows or even separate institutions would make the task of regulators easier. Each entity could then be subject to a regulating principle most suited to its nature. 


\section{Section V: Conclusion: The Regulatory Challenges AheAd}

Regulators cannot avoid acknowledging the presence of an industry handling in excess of $\$ 200$ billion, growing fast at more than $10 \%$ annually, and with a market potential possibly close to $10 \%$ of global GDP. These same facts point, however, to the need for flexibility and alertness on the part of regulators, given the emerging nature of the industry, its need to adapt to the needs of the markets it serves, the competitive pressure from conventional finance, the variations of views on the role it should play and the divergence between its practice and the theoretical model on which it is based.

Under the circumstances, regulators would want to consider a two-pronged strategy: managing the transition, and shaping the vision. In managing the transition, regulators need to promote the stability of existing IFI whose financial intermediation practices reflect the conditions of their environment and their stakeholders' demands. These practices and the risks associated with them, outlined in this paper, include: a) the presence of balance sheets with limited weight of profit and loss sharing accounts, b) an emphasis on trade and short-term financing, c) risks akin to ones faced by conventional banks, like "displacement risks", and d) market risks based on interest rates benchmarks used by conventional banks. Given the close affinity of prevailing practice of established Islamic finance and conventional banking, the regulatory framework in the transition should be mostly similar to the one applying to the regulatory framework of conventional banks. One overarching issue that needs to be addressed is the standardization of contracts and major financial instruments across the industry to facilitate growth, ease access to liquidity and enhance risk assessment capabilities. Transparency enhancements are also essential for the development of the industry.

Beyond the transition, a consensus on a vision of the nature of the industry, the role it would play in the development of the communities it serves, and how it would play it will be essential for its sustainable development. A significant intellectual effort geared at providing practical ways of achieving consistency between the demands of the market place and underlying principles will need to be ongoing. This effort will need to include 
debates that remain substantive, consultative, and evidence-based. In particular it is important to be clear on the type of Islamic financial intermediation being considered with a special attention given to the different nature of the theoretical model and current practices.

This paper outlines elements of a possible vision that would be compatible with the fundamental principles of Islamic finance. In particular it sees merit in considering separating the functions of Islamic intermediation in various windows or institutions. Such a separation could permit the development of financial intermediation more consistent with the fundamental principles of risk-sharing, materiality and no exploitation. At the same time it could help enhance the transparency of the industry. It would also bring to bear the market discipline features embedded in the nature of Islamic financial intermediation, and contribute to its stability. An Islamic financial industry incorporating such a segmentation would likely require lighter and more focused regulation, enhancing its competitiveness.

The paper contributes also conceptual benchmarks that could help shape an appropriate regulatory framework for the transition, as well as for an industry evolved toward practices more consistent with its premises. In particular the paper discusses various rationales for the introduction of regulation and the implications for their configuration. Considering the regulation of existing IFI, prevailing intermediation practices would seem to point to the need for equivalent emphasis on capital requirement, supervision and licensing, and a larger one on transparency and disclosure, compared to conventional banks. Considering the theoretical IFI model, one can expect minimal regulation with less emphasis on capital requirements, more on transparency and disclosure, probably more on screening management profile and business line in licensing, and an equivalent in supervision as compared to what applies to conventional banking. There would be also an expectation of larger reliance on direct market discipline and less on "command and control regulation". 


\section{References}

AAOIFI (1999). Statement on the Purpose and calculation of the Capital Adequacy Ratio for Islamic Banks. March 1999. The Accounting \& Auditing Organization for Islamic Financial Institutions.

Allen, F. and Douglas Gale (2000), Comparing Financial Systems, (MIT Press: Cambridge, MA, USA).

Ali, Ahmad (2002). "The Emerging Islamic Financial Architecture: The Way Ahead". Paper presented at the Fifth Harvard University Forum on Islamic Finance, April $6-7$, 2002

Archer, S. \& T. Ahmed (2003). "Emerging Standards for Islamic Financial Institutions: the Case of the Accounting \& Auditing Organization for Islamic Financial Institutions". mimeo, World Bank.

Archer, S., R. Abdel Karim \& T. Al - Deehani (1998). "Financial Contracting, Governance Structures and the Accounting Regulation of Islamic Banks: An Analysis in Terms of Agency Theory and Transaction Cost Economics". Journal of Management and Governance. Vol. 2, pp. 149 - 170.

Archer, S. \& R.A. Karim (1997). "Agency Theory, Corporate Governance and the Accounting Regulation of Islamic Banks". Research in Accounting Regulation, Supplement 1, Special International Edition, pp. $97-114$.

Ayoub, M. (2002), Islamic Banking and Finance: Theory and Practice, (State Bank of Pakistan: Karachi, Pakistan)

Baldwin, K. (2002) "Risk Management in Islamic Banks". In R. Abdel Karim \& S. Archer (Eds), Islamic Finance: Innovation \& Growth (pp. 176 - 197), published by Euromoney Books and AAOIFI

Basel Committee On Banking Supervision (BCBS) (2003), "Consultative DocumentOverview of the New Basel Capital Accord". April (2003), Bank for International Settlements.

Basel Committee On Banking Supervision (BCBS) (1998), "Enhancing Bank Transparency: Public Disclosure and Supervisory Information that Promote Safety and Soundness in Banking System". September (1998), Bank for International Settlements.

Bliss, R (2001). "Market Discipline and Subordinated Debt: A Review of Some Salient Issues", Federal Reserve Bank of Chicago. Economic Perspectives. Vol. 25 no. 1 ( $1^{\text {st }}$ Quarter 2001) pp. $24-45$.

Calomiris, C. (1999). "Building An Incentive - Compatible Safety Net". Journal of Banking \& Finance. Vol. 23 (1999), pp. 1499 - 1519. 
Chapra, U. \& H. Ahmed (2002). "Corporate Governance in Islamic Financial Institutions". Occasional Paper no. 6. Islamic Research and Training Institute: Islamic Development Bank.

Chapra U. \& T. Khan (2000). "Regulation and Supervision of Islamic Banks". Occasional Paper no. 3. Islamic Research and Training Institute: Islamic Development Bank.

Chami R., M. S. Khan and S. Sharma (2003). "Emerging Issues In Banking Regulations". IMF working paper, IMF/03/101, (Washington: International Monetary Fund, May 2003)

Cunningham, A. (2001). "Culture of Accounting: What are the Real Constraints for Islamic Finance in Riba-Based Global Economy?". Moody's Investor Services, (London, UK).

Draper, D. W. and J. W. Hoag, (1978) "Financial Intermediation and Theory of Agency," Journal of Financial and Quantitative Analysis, Vol. 13, pp. 595-611.

El Sheikkh, Fath El Rahman (2000), "The Regulation of Islamic Banks by Central Banks". The Journal of International Banking Regulation, Fall (2000), pp 43 - 49.

Errico, L. \& M. Farrahbaksh (1998). "Islamic Banking: Issues in Prudential Regulation and Supervision”. IMF working paper, IMF/98/30. (Washington: International Monetary Fund, March, 1998).

Evanoff, D. \& L. Wall (2000). "Subordinated Debt and Bank Capital Reform”. Federal Reserve Bank of Chicago. WP 2000 - 07

Fadeel, Mahmoud (2002), "Legal Aspects of Islamic Finance", in Simon Archer and Rifaat Abdel Karim (eds.) Islamic Finance: Growth and Innovation, Euromoney Books, London, UK.

Grais, W. and Z. Kantur (2003). "The Changing Financial Landscape: opportunities and Challenges for the Middle East and North Africa". World Bank Policy Research Working Paper 3050, May 2003

Greuning, H. and S. Bratanovic (2003). Analyzing and Managing Banking Risk: A Framework for Assessing Corporate Governance and Financial Risk, ( $2^{\text {nd }}$ edition). World Bank Publication

Iqbal, Zamir and Abbas Mirakhor (2002), "Development of Islamic Financial Institutions and Challenges Ahead,", in Simon Archer and Rifaat Abdel Karim (eds.) Islamic Finance: Growth and Innovation, Euromoney Books, London, UK. 
Karacadag, C. \& A. Shrivastava (2000). "The Role of Subordinated Debt in Mraket Discipline: the Case of Emerging Markets". IMF working paper, IMF/00/215. (Washington: International Monetary Fund, December, 2000).

Karim, Rifaat Ahmed Abdel (2001), "International Accounting Harmonization, Banking Regulation and Islamic Banks", The International Journal of Accounting, Vol. 36 (2), 2001, pp. 169-193.

Khan, M. Fahim (1994). "Comparative Economics of Some Islamic Financing Techniques”, Islamic Economic Studies. Vol. 2, No. 1, December 1994

Khan, M. (1987) "Islamic Interest-Free Banking: A Theoretical Analysis", in Mohsin S. Khan and Abbas Mirakhor, (ed.) Theoretical Studies in Islamic Banking and Finance, (Texas, USA: The Institute of Islamic Studies, 1987), pp. 15-36.

Khan, Mohsin S. \& A. Mirakhor (1992), "Islam and the Economic System", Review of Islamic Economics. Vol. 2, No. 1, pp. 1 - 29.

Khan, Mohsin S., (1986), "Islamic Interest - Free Banking: A Theoretical Analaysis", IMF Staff Papers, Vol. 33, pp. 1 - 27

Khan, T. (2001). "Islamic Risk Management: Towards Financial Risk Management in Islamic Finance". http://www.ieicenter.com/article/Paging2.asp?ID=27

Khan, T. \& H. Ahmed (2001). "Risk Management: An Analysis of Issues in Islamic Financial Industry". Occasional Paper no. 5. Islamic Research and Training Institute: Islamic Development Bank.

Lewis, Mervyn K. and Latifa M. Algaoud (2001), Islamic Banking, (Edward Elgar: Cheltenham, UK)

MacLachlan F. C. (2001) "Market Discipline in Bank Regulation, Panacea or Paradox?" The Independent Review, vol. VI, no. 2, Fall (2001), pp. 227-234

Maroun, Y. (2002). "Liquidity Management and Trade Financing". In R. Abdel Karim \& S. Archer (Eds), Islamic Finance: Innovation \& Growth (pp. 163 - 175), published by Euromoney Books and AAOIFI

Merton, R. (1995). "Financial Innovation and the Management and Regulation of Financial Institutions". Journal of Banking \& Finance. Vol. 19 (1995), pp. 461 - 481.

Mirakhor, A. (1989), "General Characteristics of An Islamic Economic System", in B. Al-Hasani and A. Mirakhor (Eds), Essays on Iqtisad: The Islamic Approach to Economic Problems (pp.45 - 80), published by Nur Corp., MD, USA 
Moody's Investors Service (2001). "Culture or Accounting: What Are the Real Constraints for Islamic Finance in A Riba - Based Global Economy ?". Special Comment, January 2001.

Mulajawan, D., Dar, H.A. and Hall, M.J.B. (2002): “A Capital Adequacy Framework for Islamic Banks: The Need to Reconcile Depositors's Risk Aversion With Managers' Risk Taking”. Economics Research Paper, erp 02 - 13. Loughborough University.

Rodriguez, J.L. (2002). “International Banking Regulation. Where's the Market Discipline in Basel II?". Policy Analysis, No.455, October 15, pp. 2 - 27

Sadr, Kazem and Zamir Iqbal (2002) "Choice Between Debt and Equity Contracts and Asymmetrical Information: Some Empirical Evidence," in Munawar Iqbal and David T. Llewellyn (eds.) Islamic Banking and Finance, Edward Elgar, UK.

Saleh, Nabil A. (1992), Unlawful Gain and Legitimate Profit in Islamic Law, $2^{\text {nd }}$ ed., (London, UK: Graham and Trotman), 1992.

Scholtens, L. J. R. (1993), "On the Foundation of Financial Intermediation: A Review of the Literature," Kredit and Kapital, Vol. 1, pp 112-140.

Sundararajan, V. \& L. Errico (2002). "Islamic Financial Institutions and Products in the Global Financial System: Key Issues in Risk Management and Challenges Ahead". IMF working paper, IMF/02/192. (Washington: International Monetary Fund, November, 2002).

Udovitch, Abraham L., (1981), "Bankers without Banks: Commerce, Banking and Society in the Islamic World of Middle Ages," Princeton Near East Paper No. 30 (Princeton, NJ: Princeton University Press).

Vogel, F. E. and S. L. Hayes III (1998). Islamic Law and Finance, (Boston, MA, USA: Kluwer Law).

Warde, I. (2000). Islamic Finance in the Global Economy. Edinburgh University Press.

Zaher, T. \& K. Hassan (2001). "A Comparative Literature Survey of Islamic finance and Banking". Financial Markets, Institutions \& Instruments, Vol. 10, No.4, pp. 155 - 199, November 2001

\section{Arabic References}

El - Gari, M. (2000). "Are Risks higher in Islamic banks than in their conventional counterparts ?". Paper presented in a conference on Islamic Financial Industry in Alexandria, Egypt. Prepared by the Arab Academy for Sciences, Technology and Maritime Transport, Islamic Jordanian Bank and International Investment Kuwaiti Co. 
Glossary of some Arabic terms

Annex I

\begin{tabular}{|c|c|}
\hline $\begin{array}{l}\text { Amana } \\
\text { (Demand deposits) }\end{array}$ & $\begin{array}{l}\text { Deposits held at the bank for safekeeping } \\
\text { purpose. They are guaranteed in capital } \\
\text { value, and earn no return. }\end{array}$ \\
\hline $\begin{array}{l}\text { Bay mu'ajal } \\
\text { (Pre-delivery, deferred payment) }\end{array}$ & $\begin{array}{l}\text { The seller can sell a product on the basis of } \\
\text { a deferred payment, in installments or in a } \\
\text { lump sum. The price of the product is } \\
\text { agreed upon between the buyer and the } \\
\text { seller at the time of the sale, and cannot } \\
\text { include any charges for deferring payment. }\end{array}$ \\
\hline $\begin{array}{l}\text { Bay salam } \\
\text { (Pre-payment, deferred delivery) }\end{array}$ & $\begin{array}{l}\text { The buyer pays the seller the full } \\
\text { negotiated price of a product that the seller } \\
\text { promises to deliver at a future date. }\end{array}$ \\
\hline $\begin{array}{l}\text { Fiqh } \\
\text { (Islamic jurisprudence) }\end{array}$ & $\begin{array}{l}\text { It refers to Islamic jurisprudence that } \\
\text { covers all aspects of life: religious, } \\
\text { political, social and economic. Figh is } \\
\text { mainly based on interpretations of the } \\
\text { Qur'an and Sunna (sayings and deeds of } \\
\text { the prophet). }\end{array}$ \\
\hline $\begin{array}{l}\text { Ijara } \\
\text { (Lease, lease purchase) }\end{array}$ & $\begin{array}{l}\text { A party leases a particular product for a } \\
\text { specific sum and a specific time period. In } \\
\text { the case of a lease purchase, each payment } \\
\text { includes a portion that goes toward the } \\
\text { final purchase and transfer of ownership of } \\
\text { the product. }\end{array}$ \\
\hline $\begin{array}{l}\text { Istisna } \\
\text { (Deferred payment, deferred delivery) }\end{array}$ & $\begin{array}{l}\text { A manufacturer (contractor) agrees to } \\
\text { produce (build) and to deliver a certain } \\
\text { good (or premise) at a given price on a } \\
\text { given date in the future. The price does not } \\
\text { have to be paid in advance (in contrast to } \\
\text { bay salam). It may be paid in installments } \\
\text { or part may be paid in advance while the } \\
\text { balance to be paid later on, based on the } \\
\text { preferences of the parties. }\end{array}$ \\
\hline $\begin{array}{l}\text { Ju'ala } \\
\text { (Service charge) }\end{array}$ & $\begin{array}{l}\text { A party pays another a specified amount of } \\
\text { money as a fee for rendering a specific } \\
\text { service in accordance to the terms of the } \\
\text { contract stipulated between the two parties. } \\
\text { This mode usually applies to transactions } \\
\text { such as consultations \& professional } \\
\text { services, fund placements and trust } \\
\text { services. }\end{array}$ \\
\hline Kifala & $\begin{array}{l}\text { It is a pledge given to a creditor that the } \\
\text { debtor will pay the debt, fine or liability. A } \\
\text { third party becomes surety for the payment }\end{array}$ \\
\hline
\end{tabular}




\begin{tabular}{|l|l|}
\hline $\begin{array}{l}\text { Mudaraba } \\
\text { (Trustee finance contract) }\end{array}$ & $\begin{array}{l}\text { of the debt if unpaid by the person } \\
\text { originally liable. }\end{array}$ \\
$\begin{array}{l}\text { Rabb -ul- mal (capital's owner) provides } \\
\text { the entire capital needed to finance a } \\
\text { project while the entrepreneur offers his } \\
\text { labor and expertise. Profits are shared } \\
\text { between them at a certain fixed ratio, } \\
\text { whereas financial losses are exclusively } \\
\text { borne by rabb -ul- mal. The liability of the } \\
\text { entrepreneur is limited only to his time and } \\
\text { effort. }\end{array}$ \\
\hline $\begin{array}{l}\text { Murabaha } \\
\text { (Mark-up financing) }\end{array}$ & $\begin{array}{l}\text { The seller informs the buyer of his cost of } \\
\text { acquiring or producing a specified product. } \\
\text { The profit margin is then negotiated } \\
\text { between them. The total cost is usually } \\
\text { paid in installments. }\end{array}$ \\
\hline $\begin{array}{l}\text { Musharaka } \\
\text { (Equity participation) }\end{array}$ & $\begin{array}{l}\text { The bank enters into an equity partnership } \\
\text { agreement with one or more partners to } \\
\text { jointly finance an investment project. } \\
\text { Profits and losses) are shared strictly in } \\
\text { relation to the respective capital } \\
\text { contributions. }\end{array}$ \\
\hline Qard Hassana & $\begin{array}{l}\text { These are zero - return loans that the } \\
\text { Qur'an encourages Muslims to make to the } \\
\text { needy. Banks are allowed to charge } \\
\text { borrowers a service fee to cover the } \\
\text { administrative expenses of handling the } \\
\text { loan. The fee should not be related to the } \\
\text { loan amount or maturity. }\end{array}$ \\
\hline Zakat & $\begin{array}{l}\text { The Islamic Law extracted from the Qur'an } \\
\text { and Sunna (sayings \& deeds of the } \\
\text { Prophet) }\end{array}$ \\
\hline Shariah \\
(Islamic Law)
\end{tabular}

Sources: Archer \& Ahmed (2003), Chapra \& Ahmed (2002) and Errico \& Farrahbaksh (1998) 
Annex II

Types of risks facing operating Islamic Banks

\begin{tabular}{|c|c|c|c|c|c|c|}
\hline & \multirow[b]{2}{*}{ Type of risk } & \multirow[b]{2}{*}{ Definition } & \multicolumn{2}{|c|}{ Institution } & \multicolumn{2}{|c|}{ Depositors } \\
\hline & & & Bank & Shareholders & Demand & Investment \\
\hline \multirow{4}{*}{$\begin{array}{l}\mathbf{T} \\
\mathbf{r} \\
\mathbf{a} \\
\mathrm{n} \\
\mathrm{s} \\
\mathbf{a} \\
\mathrm{c} \\
\mathrm{t} \\
\mathbf{i} \\
\mathbf{0} \\
\mathrm{n}\end{array}$} & Credit risk & $\begin{array}{l}\text { Credit risk is failure of counter- } \\
\text { party to meet his or her } \\
\text { obligations timely and on the } \\
\text { agreed terms of the contract }\end{array}$ & $\begin{array}{l}\text { The bank faces counter-party risks } \\
\text { in the various forms of contracts: } \\
\text { such as, bay mua'jal, mudaraba, } \\
\text { musharaka, murabaha, }\end{array}$ & & $\begin{array}{l}\text { They face the risk that the bank does not } \\
\text { honor requests for withdrawals at face } \\
\text { value }\end{array}$ & $\begin{array}{l}\text { They face the risk that the bank does } \\
\text { not honor requests for withdrawals at } \\
\text { market value }\end{array}$ \\
\hline & \multirow[t]{3}{*}{ Market risk } & $\begin{array}{l}\text { Market risk is the risk } \\
\text { associated with change in the } \\
\text { market value of held assets }\end{array}$ & & & & \\
\hline & & $\begin{array}{l}\text { Mark-up risk is risk of } \\
\text { divergence between the } \\
\text { murabaha contract mark-up } \\
\text { and the market benchmark rate }\end{array}$ & $\begin{array}{l}\text { The bank may incur losses if the } \\
\text { benchmark rate changes adversely }\end{array}$ & & & \\
\hline & & $\begin{array}{l}\text { Foreign Exchange risk is the } \\
\text { risk of the impact of exchange } \\
\text { rate movements on assets } \\
\text { denominated in foreign } \\
\text { currency }\end{array}$ & $\begin{array}{l}\text { This exposes the bank to risks } \\
\text { associated with their deferred- } \\
\text { trading transactions }\end{array}$ & & & \\
\hline \multirow{4}{*}{$\begin{array}{l}\text { B } \\
\mathbf{u} \\
\text { s } \\
\text { i } \\
\text { n } \\
\text { e } \\
\text { s } \\
\text { s }\end{array}$} & \multirow[t]{4}{*}{ Business risk } & $\begin{array}{l}\text { Business risk results from } \\
\text { competitive pressures from } \\
\text { existing counterparts }\end{array}$ & & & & \\
\hline & & $\begin{array}{l}\text { Displaced Commercial risk is } \\
\text { the risk of divergence between } \\
\text { assets' performance and } \\
\text { expectations for returns on } \\
\text { liabilities }\end{array}$ & $\begin{array}{l}\text { Displaced commercial risk may } \\
\text { adversely affect the value of the } \\
\text { bank's capital. Return on equity } \\
\text { goes down }\end{array}$ & $\begin{array}{l}\text { Shareholders are exposed } \\
\text { to the risk of not } \\
\text { receiving their share of } \\
\text { the bank's profit }\end{array}$ & & $\begin{array}{l}\text { Investment depositors may have to } \\
\text { forgo receiving their mudarib share }\end{array}$ \\
\hline & & $\begin{array}{l}\text { Withdrawal risk where the } \\
\text { bank is exposed to the risk of } \\
\text { withdrawal of deposits }\end{array}$ & $\begin{array}{l}\text { Withdrawal risk exposes the bank } \\
\text { to liquidity problems and erosion of } \\
\text { its franchise value }\end{array}$ & & & \\
\hline & & $\begin{array}{l}\text { Solvency risk is the risk of a } \\
\text { bank having insufficient capital } \\
\text { to continue operations }\end{array}$ & $\begin{array}{l}\text { Solvency risk may expose the bank } \\
\text { to loss of its reputation }\end{array}$ & \multicolumn{3}{|c|}{ Solvency risk exposes the different stakeholders to counter - party risks } \\
\hline
\end{tabular}




\begin{tabular}{|c|c|c|c|c|c|c|}
\hline $\begin{array}{l}\text { T } \\
\mathbf{r} \\
\mathrm{e} \\
\mathrm{a} \\
\mathrm{s} \\
\mathrm{u} \\
\mathrm{r} \\
\mathrm{y}\end{array}$ & $\begin{array}{l}\text { Asset \& } \\
\text { Liability } \\
\text { Management } \\
\text { (ALM) risk }\end{array}$ & $\begin{array}{l}\text { Asset \& Liability Management } \\
\text { (ALM) risk is a balance sheet } \\
\text { mismatch risk resulting from } \\
\text { the difference in terms and } \\
\text { conditions of a bank's portfolio } \\
\text { on its asset \& liability sides }\end{array}$ & $\begin{array}{l}\text { This may adversely affect the } \\
\text { bank's capital }\end{array}$ & & & \\
\hline $\begin{array}{l}\text { R } \\
\mathbf{i} \\
\mathbf{S}\end{array}$ & Liquidity risk & $\begin{array}{l}\text { Liquidity risk is the risk of } \\
\text { bank's inability to access liquid } \\
\text { funds to meet its obligations }\end{array}$ & $\begin{array}{l}\text { The bank is exposed to risk of } \\
\text { failure to honor requests for } \\
\text { withdrawals from its depositors }\end{array}$ & & $\begin{array}{l}\text { They face the risk of not being able to } \\
\text { access their deposits when they need to }\end{array}$ & \\
\hline $\begin{array}{l}\mathbf{k} \\
\mathbf{s}\end{array}$ & Hedging risk & $\begin{array}{l}\text { Hedging risk is the risk of } \\
\text { failure to mitigate \& manage } \\
\text { the different types of risks }\end{array}$ & $\begin{array}{l}\text { This increases the bank' s overall } \\
\text { risk exposure }\end{array}$ & & & \\
\hline \begin{tabular}{l|} 
G \\
o \\
$\mathbf{v}$ \\
e
\end{tabular} & Operational risk & $\begin{array}{l}\text { Operational risk is the risk of } \\
\text { failure of internal processes as } \\
\text { related to people or systems }\end{array}$ & $\begin{array}{l}\text { The bank incurs losses due to } \\
\text { occurrence of that risk hence may } \\
\text { fail to meet its obligations towards } \\
\text { the different stakeholders }\end{array}$ & $\begin{array}{l}\text { This risk adversely affects } \\
\text { return on equity }\end{array}$ & & $\begin{array}{l}\text { This risk adversely affects return on } \\
\text { assets }\end{array}$ \\
\hline $\begin{array}{l}\mathbf{r} \\
\mathbf{n} \\
\mathbf{a} \\
\mathbf{n} \\
\mathbf{c} \\
\mathbf{e}\end{array}$ & Fiduciary risk & $\begin{array}{l}\text { - Fiduciary risk is the risk of } \\
\text { facing legal recourse action in } \\
\text { case the bank breaches its } \\
\text { fiduciary responsibility towards } \\
\text { depositors and shareholders. } \\
\text { - Risk of loss of reputation }\end{array}$ & $\begin{array}{l}\text { Legal recourse may lead to } \\
\text { charging the bank a penalty or a } \\
\text { compensation. This may lead to } \\
\text { withdrawal of deposits, sale of } \\
\text { shares, bad access to liquidity or } \\
\text { decline in the market price of } \\
\text { shares if listed on the stock } \\
\text { exchange }\end{array}$ & $\begin{array}{l}\text { This risk adversely affects } \\
\text { return on equity }\end{array}$ & & $\begin{array}{l}\text { This risk exposes investment } \\
\text { depositors to economic losses }\end{array}$ \\
\hline $\begin{array}{l}\mathbf{i} \\
\mathbf{s} \\
\mathbf{k} \\
\mathrm{S}\end{array}$ & $\begin{array}{l}\text { Transparency } \\
\text { risk }\end{array}$ & $\begin{array}{l}\text { Transparency risk is the risk of } \\
\text { consequences of decisions } \\
\text { based on inaccurate or } \\
\text { incomplete information which } \\
\text { is the outcome of poor } \\
\text { disclosure }\end{array}$ & Losses may occur as a result of bad & cisions based on inaccurate & incomplete information & \\
\hline $\begin{array}{l} \\
\text { y } \\
\mathbf{s} \\
\mathbf{t} \\
\mathrm{e} \\
\mathbf{m}\end{array}$ & $\begin{array}{l}\text { Business } \\
\text { environment } \\
\text { risk }\end{array}$ & $\begin{array}{l}\text { Business environment risk is } \\
\text { the risk of poor broad } \\
\text { institutional environment } \\
\text { including legal risk whereby } \\
\text { banks are unable to enforce } \\
\text { their contracts. }\end{array}$ & $\begin{array}{l}\text { Business } \text { environment risk } \\
\text { increases banks' exposure to } \\
\text { counter-party risk as weak } \\
\text { contracts are not easily enforceable }\end{array}$ & & & \\
\hline $\begin{array}{l}\mathbf{R} \\
\mathbf{i}\end{array}$ & $\begin{array}{l}\text { Institutional } \\
\text { risk }\end{array}$ & $\begin{array}{l}\text { Institutional risk is the risk of } \\
\text { divergence between product } \\
\text { definition and practices }\end{array}$ & $\begin{array}{l}\text { Institutional risk exposes the bank } \\
\text { to counter-party risks due to the } \\
\text { unsettled nature of the contract }\end{array}$ & & & \\
\hline $\begin{array}{l}\mathbf{s} \\
\mathbf{k} \\
\mathbf{s}\end{array}$ & Regulatory risk & $\begin{array}{l}\text { Regulatory risk is the risk of } \\
\text { non-compliance with } \\
\text { regulations due to confusion, } \\
\text { bad management or mistakes }\end{array}$ & $\begin{array}{l}\text { Banks may be penalized for non } \\
\text { complying with the rules or } \\
\text { regulations. It could be an issue } \\
\text { with the regulator or supervisor }\end{array}$ & & & \\
\hline
\end{tabular}


